\title{
The Stoneflies (Plecoptera, Insecta) of the northwestern Iberian Peninsula
}

\author{
G. Vinçon ${ }^{1 *}$, I. Pardo ${ }^{2}$ \\ 174 rue du Drac, F-38000 Grenoble, France \\ 2 Área de Ecología, Facultad de Ciencias, Universidad de Vigo, E-36200 Vigo, Spain
}

\begin{abstract}
73 species and subspecies are reported from the North West of the Iberian Peninsula, including 10 new taxa described in the last four years. 14 species are new for the Cantabrian Cordillera, 1 for Galicia, 9 for the Sierra de la Demanda and 2 for the Sierra del Moncayo. The systematic status of some species is modified: Protonemura pyrenaica pyrenaica and P. pyrenaica asturica are restored to specific level; Leuctra lusitanica is considered as a subspecies of L. lamellosa; Nemoura cinerea umbrosa is a valid subspecies of $N$. cinerea cinerea. The stonefly faunistic lists of the Cantabrian Cordillera, Galicia, Demanda and Moncayo are updated. Species distribution patterns and faunistic relations with the neighbouring regions are analyzed. Classification and ordination analyses based on species presence, enable identification of bioclimatic and biogeographical patterns of Plecoptera distribution in the North of the Iberian Peninsula.
\end{abstract}

Keywords : Plecoptera, Spain, Cantabrian Cordillera, Galicia.

\section{Introduction}

The stoneflies of the Cantabrian Cordillera were studied for the first time at the beginning of the twentieth century by Navás (1901, 1908, 1915 and 1917). Thirty years later, Aubert (1948) revised the numerous species described by Navás and subsequently made an important contribution with the description of two endemic species, Leuctra espanoli Aubert, 1956 and L. besucheti Aubert, 1962, together with the first catalogue of Spanish stoneflies (Aubert 1963). In the same period, a third endemic species was described by Illies: Leuctra wilmae Illies, 1954. In the following decades, other important faunistic studies of northwestern Spain stoneflies were carried out by Zwick (1972), Berthélemy \& González del Tánago (1983), González del Tánago (1984), Membiela Iglesia (1989, 1990, 1996), Pardo (1989), Pardo et al. (1991), Vidal López \& Membiela Iglesia (1993). At the same time faunistic lists based on the study of stonefly nymphs were published by Puig-Garcia et al. (1984), Presa et al. (1990), Rodríguez et al. (1994), with applied ecology

\footnotetext{
* Corresponding author: E-mail: Vincon@kls-logistic.fr
}

programs. Moreover, the whole bibliography concerning Iberian stoneflies was summarized in SánchezOrtega \& Alba-Tercedor (1987) and in Sánchez-Ortega \& Tierno (1996). Between 1987 and 2000, intensive collections of adult stoneflies were made in the Spanish Cantabrian Cordillera and Galician mountains, covering a total of 118 localities. We have captured 8493 stonefly specimens belonging to 73 different taxa, including 10 new species or subspecies (Vinçon \& Ravizza 1998, 1999, 2000, Vinçon \& Sánchez-Ortega 2002, Vinçon \& Pardo 2003). We present here the first complete study of the stoneflies living in the northwestern part of the Iberian Peninsula (Cantabrian Cordillera and Galaico-Portuguese Mountains).

\section{Study area}

The North West of the Iberian Peninsula may be divided into three biogeographic units: The first unit is the Litoral-sublitoral area that comprises coastal territories and a group of diverse valleys of lower altitude and extension in comparison with most other Iberian territories. The second unit is the mountainous area (mainly the Cantabrian Cordillera) that separates the Litoral-sublitoral area from the interior part of the Ibe- 
rian Peninsula; this mountainous area constitutes the watershed between the Cantabric, Atlantic and Mediterranean basins. The third unit, south of the mountainous region, is composed of wide sedimentary basins of Cenozoic origin, which condition a low-relief landscape, the septentrional Iberian meseta (Peinado \& Rivas-Martínez 1987, Ramil-Rego et al., 1988 a,b). Within the mountainous area, the Cantabrian Cordillera, is characterized by its complex orography of high and frequent unevenness with more than $2000 \mathrm{~m}$ of elevation over short distances. In its most eastern extreme the Cantabrian Cordillera covers the Basque mountains, formed by mountainous alignments of lower altitude (Ortzainzurieta, 1570 m, Aitzkorri, 1544 m, Gorbea, $1475 \mathrm{~m}$, Adi, $1459 \mathrm{~m}$ ), running in an easternwestern direction, separating the Cantabric and Mediterranean basins. The separation line between the Cantabrian Cordillera and the Pyrenees follows the line San Sebastian - Pamplona. To the West, the Cantabrian Cordillera gives way to a territory less heterogeneous and of lower elevation (Pena Rubia, $1821 \mathrm{~m}$, Manzaneda, $1778 \mathrm{~m}$, Xistral, $1050 \mathrm{~m}$ ) where it is frequent to find mountains isolated between valleys and small sedimentary depressions. This heterogeneous group of mountains is locally denominated the Galaico-Portuguese Mountains. Administratively this territory corresponds to Galicia (Coruña, Lugo, Ourense y Pontevedra), Zamora and Portugal (Minho, Tras-osMontes). The separation line between the Cantabrian Cordillera and the Galaico-Portuguese Mountains follows the Galician border and the line Ponferrada León.

\section{Material and methods}

This inventory has required 20 different collecting trips between 1987 and 2000: 3-6 July 87, 3-4 August 87, 29 August - 1 September 87, 29 July - 5 August 88, 11-12 August 88, 16-18 August 88, 31 August 88, 29 July 90, 3-5 May 91, 20-21 December 92, 9-11 April 93, 7-9 November 93, 19-21 Mars 94, 11-12 October 94, 14-17 Mars 95, 16-19 February 96, 24-26 April 96, 19-20 September 96, 28-30 November 97 and 2-3 June 00 .

In order to perform an exhaustive inventory of the stonefly fauna, the sampling stations were chosen as diverse as possible all along the studied area (Fig. 1). The insects were collected in different kinds of water courses (springs, brooks, torrents and rivers), with a special attention for the high altitude places which often required long walks. The stoneflies where captured during a period of approximately an hour in each collecting place, generally using a Japanese net and searching afterwards in the stream bank vegetation and in the stones. The stations were visited several times during the year, including the coldest season.

The Jaccard similarity index using presence-absence of species (Table 1) and the UPGMA clustering method were applied (Fig. 2a) to explore faunistic similarities among stonefly faunas in the northwestern part of the Iberian peninsula. A complementary ordination analysis by Detrended Correspondence Analysis (DCA), with the option of downweighing rare species allowed better comparison of the degree of faunistic similarities among the groups of the classification (Fig. 2b). The classification analysis was performed with the NTSYS-pc package (version 1.6, Applied Biosta-

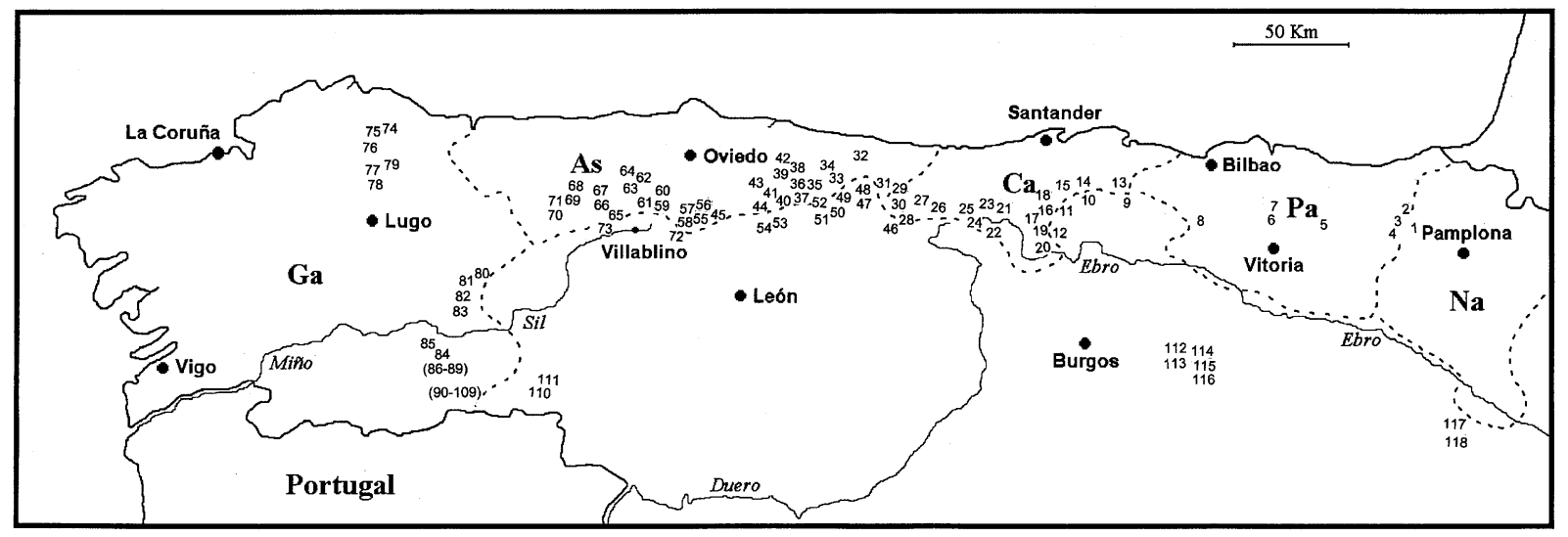

Fig 1. Distribution of the 118 sampling sites in the North West of the Iberian Peninsula. 
Table 1. Stonefly distribution in the northwestern Iberian Peninsula. Cantabrian Cordillera: West $=$ west Asturias + west León (westwards the line Oviedo-León), Central = east Asturias + east León (eastwards the line Oviedo-León), East $=$ Cantabria + Burgos + Palencia, Basque mountains, $*=$ microendemic species, $!=$ species that slightly extend in the western extremity of the Pyrenees. Galicia: South (southwards the Miño and Sil), North (northwards the Miño and Sil). Teleno and Cabrera: southwards the line Ponferrada-León. Pyr.: Pyrenees.

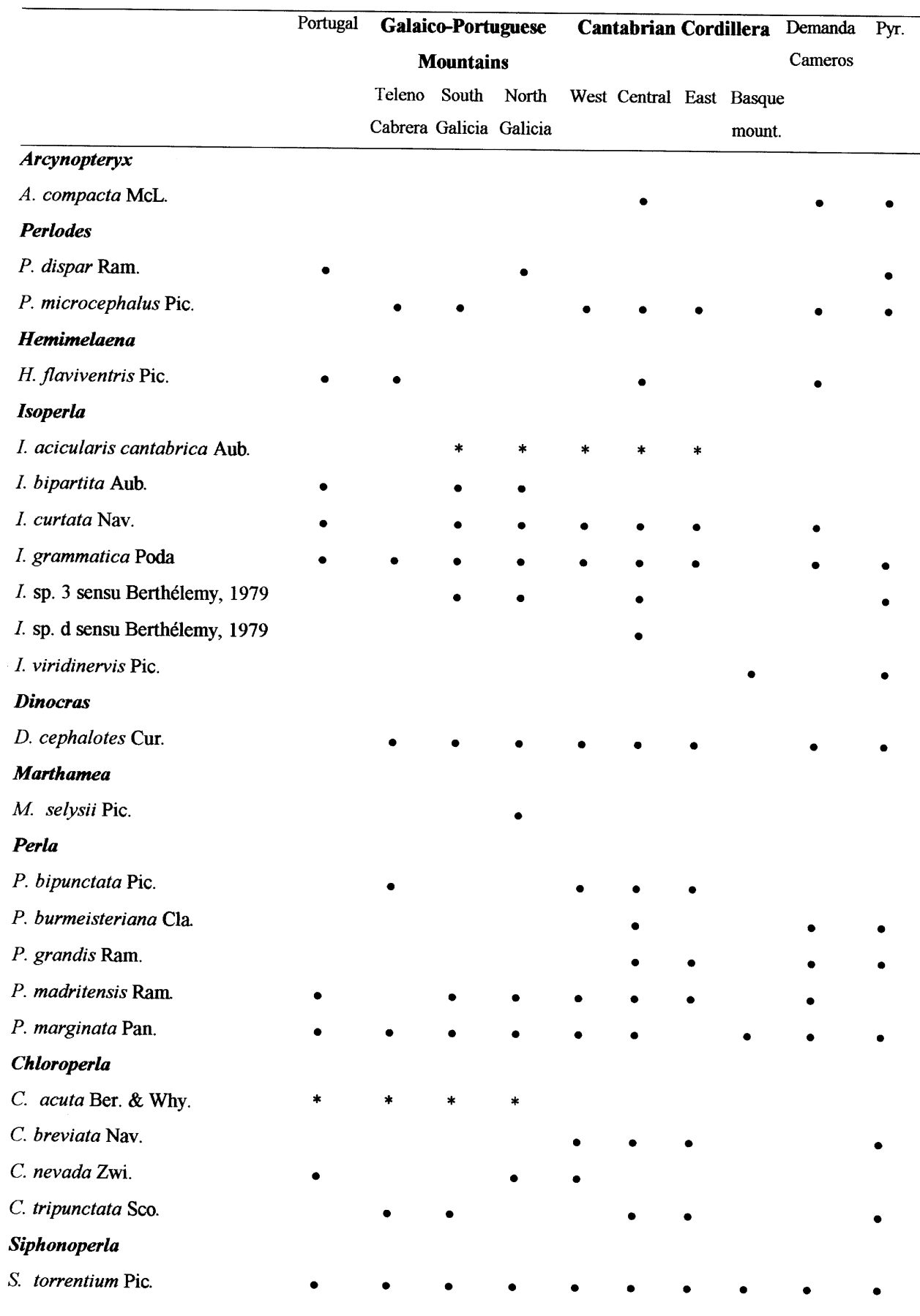


Table 1. Continued.

\begin{tabular}{|c|c|c|c|c|c|c|c|c|c|c|}
\hline & \multirow[t]{2}{*}{ Portugal } & \multicolumn{3}{|c|}{$\begin{array}{c}\text { Galaico-Portuguese } \\
\text { Mountains }\end{array}$} & \multicolumn{4}{|c|}{ Cantabrian Cordillera } & \multirow{2}{*}{$\begin{array}{l}\text { Demanda } \\
\text { Cameros } \\
\text { e }\end{array}$} & \multirow[t]{2}{*}{ Pyr. } \\
\hline & & $\begin{array}{l}\text { Teleno } \\
\text { Cabrera }\end{array}$ & $\begin{array}{l}\text { South } \\
\text { Galicia }\end{array}$ & $\begin{array}{l}\text { North } \\
\text { Galicia }\end{array}$ & West & Central & East & $\begin{array}{l}\text { Basque } \\
\text { mount. }\end{array}$ & & \\
\hline \multicolumn{11}{|l|}{ Taeniopteryx } \\
\hline T. schoenemundi Mer. & $\bullet$ & $\bullet$ & & $\bullet$ & $\bullet$ & $\bullet$ & $\bullet$ & & & - \\
\hline \multicolumn{11}{|l|}{ Brachyptera } \\
\hline B. arcuata Klp. & $\bullet$ & $\bullet$ & $\bullet$ & $\bullet$ & $\bullet$ & $\bullet$ & - & & $\bullet$ & \\
\hline B. braueri Klp. & & $\bullet$ & & & & $\bullet$ & $\bullet$ & & & - \\
\hline B. monilicornis Pic. & $\bullet$ & $\bullet$ & & & & $\bullet$ & $\bullet$ & & & $\bullet$ \\
\hline B. risi Mor. & & & & & & & $\bullet$ & $\bullet$ & $\bullet$ & $\bullet$ \\
\hline
\end{tabular}

\section{Rhabdiopteryx}

$R$. antoninoi Vin. \& Rav.

$R$. thienemanni Illies

Amphinemura

A. guadarramensis Aub.

A. hibernatarii Par.

A. sulcicollis Ste.

A. triangularis Ris.

Protonemura

P. asturica Aub.

P. beatensis Des

P. brittaini Vin. \& Rav.

P. fusunae Vin. \& Rav

P. globosa Ber. \& Why.

P. hiberiaca Aub.

P. hispanica Aub.

$P$. intricata intricata $\mathrm{Ris}$

P. isabellae Vin. \& Rav.

P. meyeri Pic.

P. navacerrada Aub.

P. praecox Mor.

$P$. pyrenaica Mos.

P. risi spinulosa Nav.

\section{Nemoura}

N. cambrica Ste.

N. ceciliae Aub. 
Table 1. Continued.

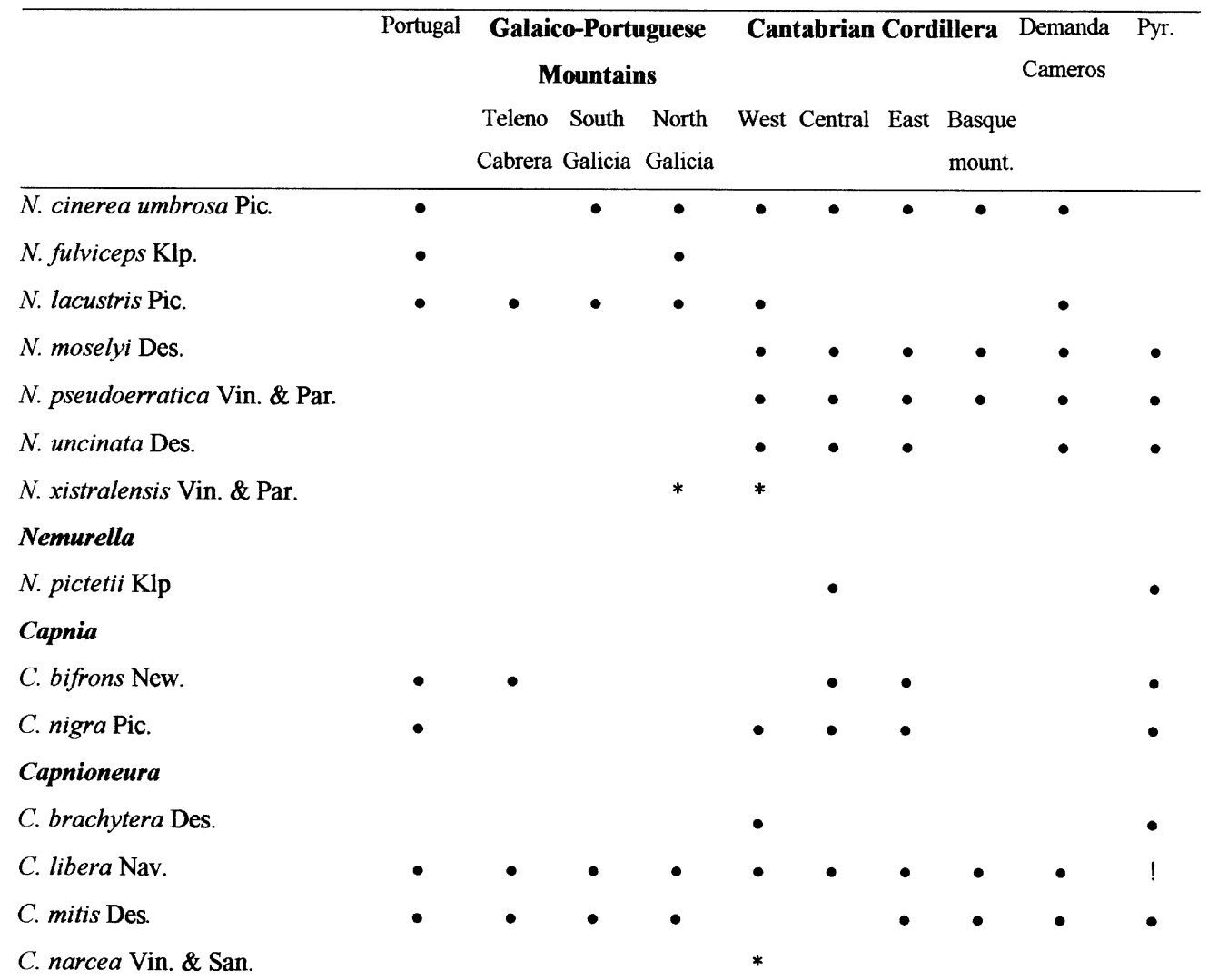

\section{Leuctra}

L. alosi Nav.

L. auriensis Mem.

L. aurita Nav.

L. besucheti Aub.

L. castillana Aub.

L. despaxi Mos.

L. espanoli Aub.

L. franzi franzi Aub

L. fusca fusca $\mathrm{L}$.

L. gallaeca Mem.

L. geniculata Ste.

L. hiberiaca Aub.

L. hippopus Kem.

L. hispanica Aub.

L. inermis Kem.

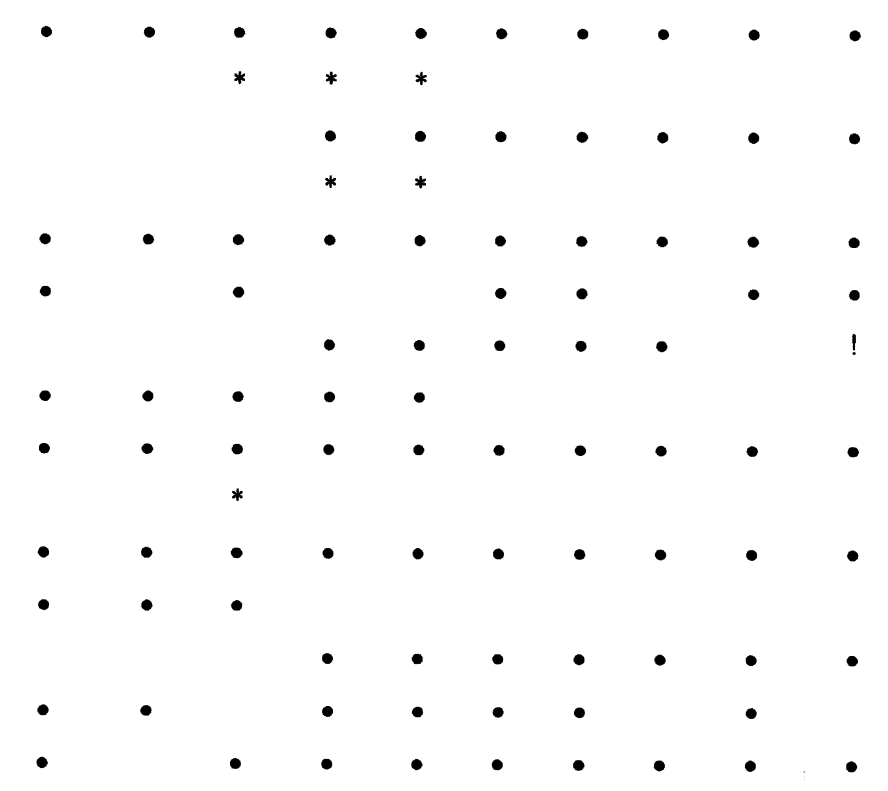


Table 1. Continued.

\begin{tabular}{|c|c|c|c|c|c|c|c|c|c|c|}
\hline & \multirow[t]{2}{*}{ Portugal } & \multicolumn{3}{|c|}{$\begin{array}{c}\text { Galaico-Portuguese } \\
\text { Mountains }\end{array}$} & \multicolumn{4}{|c|}{ Cantabrian Cordillera } & \multirow[t]{2}{*}{$\begin{array}{l}\text { Demanda } \\
\text { Cameros }\end{array}$} & \multirow[t]{2}{*}{ Pyr. } \\
\hline & & $\begin{array}{l}\text { Teleno } \\
\text { Cabrera }\end{array}$ & $\begin{array}{l}\text { South } \\
\text { Galicia }\end{array}$ & $\begin{array}{l}\text { North } \\
\text { Galicia }\end{array}$ & West & Central & $\begin{array}{r}\text { East } \mathrm{B} \\
\mathrm{n}\end{array}$ & $\begin{array}{l}\text { Basque } \\
\text { mount. }\end{array}$ & & \\
\hline L. kempnyi Mos. & & & & & & & $\bullet$ & $\bullet$ & & $\bullet$ \\
\hline L. lamellosa lamellosa Des. & & & & & $\bullet$ & $\bullet$ & $\bullet$ & $\bullet$ & $\bullet$ & $\bullet$ \\
\hline L. lamellosa lusitanica Aub. & * & * & * & $*$ & * & & & & & \\
\hline L. madritensis Aub. & $\bullet$ & $\bullet$ & $\bullet$ & $\bullet$ & $\bullet$ & $\bullet$ & $\bullet$ & & $\bullet$ & \\
\hline L. major Bri. & & & & & $\bullet$ & & & $\bullet$ & & $\bullet$ \\
\hline L. maroccana Aub. & $\bullet$ & - & $\bullet$ & - & $\bullet$ & $\bullet$ & $\bullet$ & $\bullet$ & $\bullet$ & $!$ \\
\hline L. microstyla micr. Vin. \& Rav. & & & & & & $*$ & & & & \\
\hline L. microstyla nalon Vin. \& Rav. & & & & & * & $*$ & & & & \\
\hline L. microstyla saja Vin. \& Rav. & & & & & & & $*$ & & & \\
\hline L. pseudocylindrica Des. & & & & & & & & $\bullet$ & & $\bullet$ \\
\hline L. stupeningi Illies & $\bullet$ & $\bullet$ & $\bullet$ & $\bullet$ & $\bullet$ & & & & & \\
\hline L. wilmae Illies & & & & & & & $*$ & & & \\
\hline Total species + subspecies: & & 37 & 42 & 49 & 57 & 55 & 54 & 26 & 42 & \\
\hline Total microendemic species & & 2 & 7 & 9 & 11 & 5 & 6 & $\mathbf{0}$ & $\mathbf{0}$ & \\
\hline Rate of microendemism (\%) & & 5.4 & 16.7 & 18.4 & 19.3 & 9.1 & 11.1 & $\mathbf{0}$ & $\mathbf{0}$ & \\
\hline
\end{tabular}

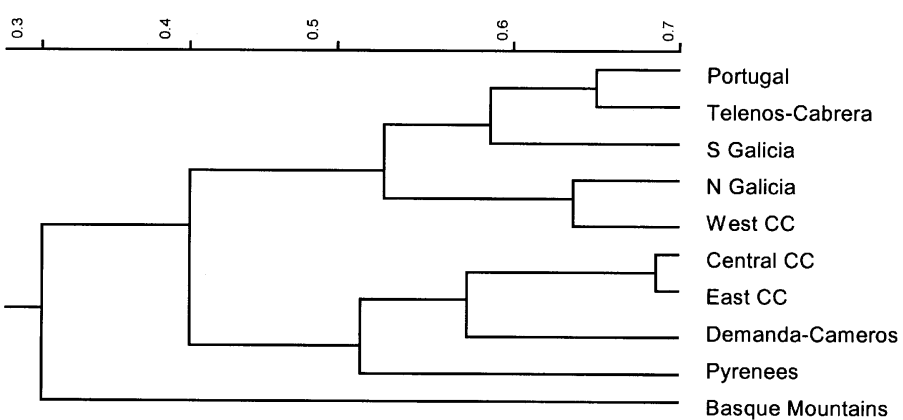

Fig. 2 a. Cluster analysis based on the presence of 91 stoneflies species and subspecies in 10 geographic areas from NW to NE of the Iberian Peninsula. 


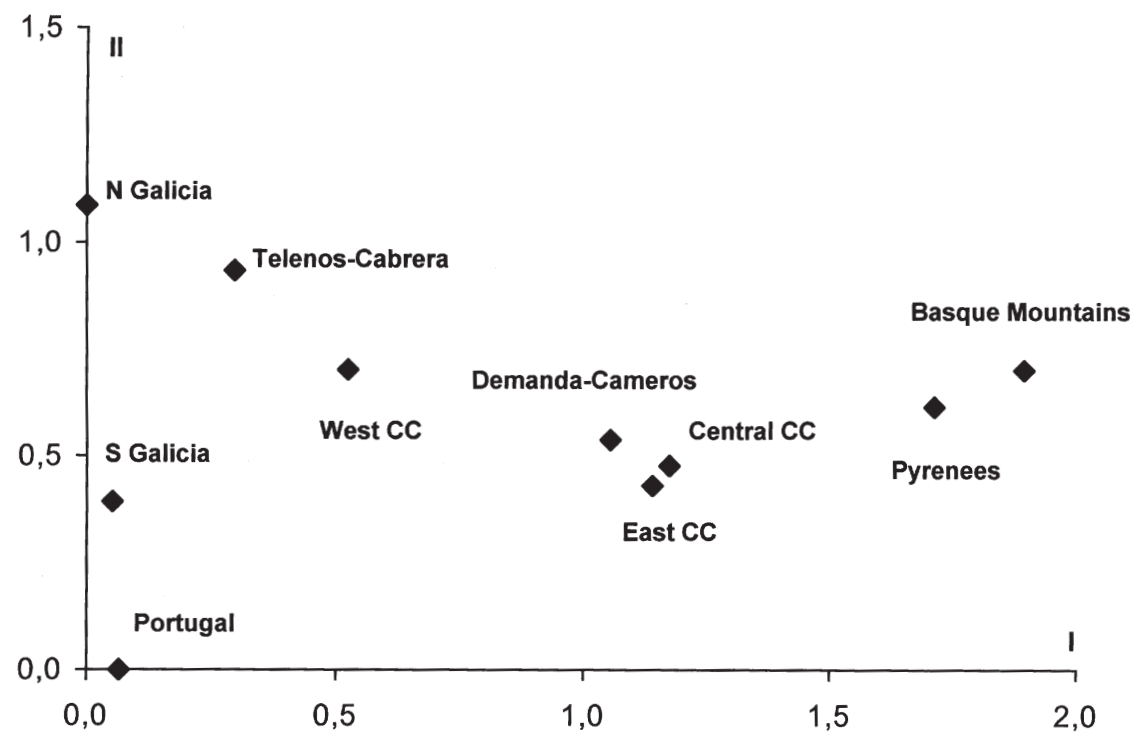

Fig. 2b. Ordination (DCA) of geographic areas based on the presence of 91 stoneflies species and subspe-

tistics, Inc., 1990) and the DCA ordination by CANOCO (Ter Braak, version 3.12, 1988-1991).

\section{List of species}

In the following list we present the results of our collections. The collecting sites are numbered following the station list given in appendix 1. Morphological, biogeographical and ecological notes are provided. The distribution altitudinal range and the highest recorded altitude in the Iberian Peninsula or Pyrenees are indicated for each species (Sánchez-Ortega \& AlbaTercedor 1987, Berthélemy 1966, and private collection).

\section{Arcynopteryx compacta (McLachlan, 1872)}

Material: St. 33, 41, 117, 118 (1 male, 1 female, 2 larva). Ecology: cold stenothermal, strongly crenophilic species, restricted to the headwater of brooks near to their source, (1200-1800 $\mathrm{m}$ in the Cantabrian Cordillera, up to $2500 \mathrm{~m}$ in the Pyrenees). Flight period: spring (VI). Distribution: Holarctic. northern Iberian Peninsula (Cantabrian Cordillera, Cameros, Moncayo, Pyrenees).

\section{Perlodes microcephalus (Pictet, 1833)}

Material: St. 22, 44, 51, 86, 100 (1 male, 3 females, 1 larva). Ecology: eurytopic species (450-1680 m), up to $2700 \mathrm{~m}$ in the Sierra Nevada. Flight period: spring (III-VI). Distribution: Europe.

\section{Isoperla acicularis cantabrica Aubert, 1956}

Material: St. 9, 16, 30, 34, 51, 61, 65, 71, 86, 96, 100, 102 (30 males, 42 females). Ecology: orophilic species living in mountain brooks and torrents (900$1680 \mathrm{~m}$ ). Flight period: summer (VI-IX). Distribution: Cantabrian Cordillera.

\section{Isoperla curtata Navás, 1924}

Material: St. 30, 43, 49, 51, 61, 65, 68, 69, 73, 115, 116 (56 males, 69 females). Ecology: various kinds of mountain brooks and torrents $(800-1500 \mathrm{~m})$. Flight period: spring and summer (IV-IX). Distribution: Iberian Peninsula.

\section{Isoperla sp. 3 (sensu Berthélemy, 1979)}

This species corresponds to the morph sp. 3 distinguished in a preliminary article concerning the Pyrenean Isoperla (Berthélemy, 1979). Material: 43, 95 (4 males, 2 females). Ecology: various water courses in the foothills (280-860 m). Flight period: summer (VVII). Distribution: western Europe. New for the Cantabrian Cordillera.

\section{Isoperla sp. d (sensu Berthélemy, 1979)}

Material: St. 40 (1 male) Ecology: orophilic species (500-1900 m). Flight period: VI-VII. Distribution: 
Pyrenees and Cantabrian Cordillera. New for the Cantabrian Cordillera.

\section{Isoperla viridinervis (Pictet, 1865)}

Material: St. 2 (1 male, 1 female). Ecology: cold stenothermal, crenophilic species living in mountain springs and brooks, above $800 \mathrm{~m}$ (up to $2400 \mathrm{~m}$ in the Pyrenees). Flight period: summer (VII). Distribution: Pyrenees, Basque mountains. New for the Cantabrian Cordillera.

\section{Dinocras cephalotes (Curtis, 1827)}

Material: St. 15, 16, 22, 28, 34, 43, 61, 95, 100, 102, 105, 117 (4 males, 11 females, 6 larva). Ecology: eurytopic species $(600-1600 \mathrm{~m})$. The higher altitudinal limit is $2800 \mathrm{~m}$ in the Sierra Nevada (Aubert 1956). Flight period: summer (VI-VIII). Distribution: Europe.

\section{Perla madritensis Rambur, 1842}

Material: St. 22, 28, 49, 54, 79 (1 male, 6 females). Ecology: orophilic species living in mountain torrents and brooks (820-1600 m), up to $2000 \mathrm{~m}$ in the Sierra de Guadarrama (Aubert 1956, 1963). Flight period: spring and summer (IV-VIII). Distribution: Iberian Peninsula.

\section{Chloroperla acuta Berthélemy \& Whytton, 1980}

Material: St. 91, 100 (16 males, 22 females). Ecology: orophilic species $(650-1540 \mathrm{~m})$. Flight period: summer (VII-VIII). Distribution: Lusitanian species, living from Galicia to northern Portugal (Tras os Montes and Minho).

\section{Chloroperla breviata Navás, 1918}

Material: St. 40, 41, 47, 51, 61, 65 (13 males, 6 females). Ecology: cold stenothermal, strongly orophilic species living in high altitude brooks and torrents (1200-1500 m, in the Cantabrian Cordillera, up to 2700 in the Pyrenees). Flight period: summer (VIVIII). Distribution: Pyrenees, Cantabrian Cordillera.

\section{Chloroperla nevada Zwick, 1967}

Chloroperla tripunctata nevada Zwick, 1967

Chloroperla nevada Berthélemy \& Whytton, 1980

Material: St. 71 (2 males, 1 female). Ecology: in the Lusitanian region it lives in the foothills $(80-900 \mathrm{~m})$ (Pardo 1992), but in Andalusia it is strongly orophilic (1100-2200m). Flight period: spring (IV-V). Distribution: from southern to northwestern Iberian Peninsula. New for the Cantabrian Cordillera.

\section{Chloroperla tripunctata (Scopoli, 1963)}

Material: St. 43, 48 (2 males, 3 females). Ecology: torrents and brooks in the montane zone (320-1400 m), up to $1900 \mathrm{~m}$ in the Pyrenees. Flight period: summer (VI-VIII). Distribution: Europe. Scarce in the Cantabrian Cordillera.

\section{Siphonoperla torrentium (Pictet, 1841)}

Material: St. 1, 2, 4, 7, 9, 16, 18, 19, 21, 26, 27, 28, $30,34,35,36,40,47,48,51,52,55,61,62,63,65,71$, 79, 89, 91, 93, 95, 96, 97, 98, 100, 102, 103, 104, 105, 106, 107, 111, 116, 117 (358 males, 444 females). Ecology: widespread, eurytopic species (30-1600 m) (Pardo 1992), up to $2200 \mathrm{~m}$ in the Pyrenees. Flight period: spring and summer (III-IX). Distribution: Europe.

\section{Brachyptera arcuata (Klapálek, 1902)}

Material: St. 9, 21, 37, 50, 55, 60, 109, 110, 114 (74 males, 31 females). Ecology: various kinds of mountain torrents and brooks (600-1300 m, up to $1800 \mathrm{~m}$ in the Sierra de Guadarrama). Flight period: spring (IIIVI). Distribution: northern Iberian Peninsula.

\section{Brachyptera risi (Morton, 1896)}

Material: St. 1, 6, 9, 114 (4 males, 4 females). Ecology: eurytopic species (600-1000 m, up to $2000 \mathrm{~m}$ in the Pyrenees). Flight period: spring (IV-V). Distribution: Europe. In the Iberian Peninsula it is limited to the northern part (Pyrenees, Cantabrian Cordillera, Demanda-Cameros). New for the Sierra de la Demanda.

\section{Rhabdiopteryx antoninoi Vinçon \& Ravizza,} 1999

Material: St. 23, 55, 61 (4 males, 7 females). Ecology: orophilic species living in torrents and brooks in the montane zone $(900-1300 \mathrm{~m})$. Flight period: winter (II-III). Distribution: Cantabrian Cordillera.

\section{Amphinemura guadarramensis (Aubert, 1956)}

Material: St. 22, 27, 43, 77, 78, 102, 104 (12 males, 13 females). Ecology: brooks and torrents of moderate altitudes (20-1800 m) (Pardo 1989). Flight period: summer (VI-VIII). Distribution: Iberian Peninsula. New for the Cantabrian Cordillera.

\section{Amphinemura hibernatarii Pardo, 1989}

Material: St. 74, 76, 86 (19 males, 23 females). Ecology: crenophilic species living in mountain springs and brooklets (500-1680 m). Flight period: summer (VII). Distribution: Galicia. 


\section{Amphinemura sulcicollis (Stephens, 1836)}

Material: St. 2, 7, 9, 16, 23, 28, 30, 34, 41, 48, 49, 55, 100, 104, 115, 117 (13 males, 87 females). Ecology: widespread, eurytopic species (300-1600 m, up to $2400 \mathrm{~m}$ in the Pyrenees). Flight period: summer (VVIII). Distribution: Europe.

\section{Protonemura asturica (Aubert, 1954), new sta-} tus

Nemoura (Protonemura) lacustris: Aubert, 1952

Nemoura (Protonemura) asturica: Aubert, 1954

Protonemura penalara: Aubert, 1956

Protonemura pyrenaica asturica: Aubert, 1963

New for the Sierra de la Demanda. This species, previously considered as a subspecies of $P$. pyrenaica, is restored to the specific level because both species $P$. pyrenaica and $P$. asturica have been collected together in the Basque mountains, without any intermediate specimens. In the middle and western part of the Cantabrian Cordillera, the variability of $P$. asturica is rather high but the specimens are always clearly different from $P$. pyrenaica. This high variability suggests that two different forms of P. asturica could live in the Cantabrian Cordillera. Material: St. 7, 10, 11, 13, 14 $16,21,23,24,26,28,30,31,33,34,35,36,37,40,41$, $42,43,50,51,52,55,60,61,62,63,65,68,69,71,73$, 74, 76, 79, 84, 89, 91, 93, 95, 99, 100, 101, 102, 103, 104, 109, 111, 112, 115, 116 (223 males, 234 females). Ecology: widespread, eurytopic mountain species (40$2000 \mathrm{~m}$ ). Flight period: spring and summer (II-VIII) ($\mathrm{XI}$ in the crenal). Distribution: northwestern Iberian Peninsula, including the Sierra de Guadarrama.

\section{Protonemura beatensis (Despax, 1929)}

Material: St. 22, 24, 61 (3 males). Ecology: brooks and torrents in the montane zone (900-1500 m, up to $2200 \mathrm{~m}$ in the Pyrenees). Flight period: autumn (IX-XI). Distribution: Pyrenees and Cantabrian Cordillera.

\section{Protonemura brittaini Vinçon \& Ravizza, 1998}

Material: St. 18, 21, 23 (2 males, 3 females). Ecology: cold stenothermal species living in mountain torrents and brooks (800-1200 m). Flight period: autumn (IX-XI). Distribution: eastern Cantabrian Cordillera.

\section{Protonemura fusunae Vinçon \& Ravizza, 1998}

Material: St. 62, 63, 64, 71, 76 (2 males, 3 females). Ecology: crenophilic species, living in springs and brooklets of moderate altitude $(700-1000 \mathrm{~m})$. Flight period: summer and autumn (VI-XI). Distribution: northern Galicia and western Cantabrian Cordillera where it is always very scarce.

\section{Protonemura globosa Berthélemy \& Whytton,} 1980

Material: St. 62, 64, 67, 68, 69, 71, 79, 80, 82, 100, 102 (12 males, 14 females). Ecology: species living in various brooks and torrents, mainly in the foothills (40-1160 m). Flight period: winter and spring (XI-VI). Distribution: Lusitanian species (western Cantabrian Cordillera, Galicia and Portugal). New for the Cantabrian Cordillera.

\section{Protonemura hiberiaca Aubert, 1963}

Material: St. 17, 23, 24, 61, 66, 84, 90, 116 (15 males, 18 females). Variability: in the Cantabrian Cordillera, the male of $P$. hiberiaca is highly variable considering the finger-shaped extension of the paraproct median lobe. In some specimens this extension is very short, in others it is long and thin like in Aubert's description (1963). Both forms or intermediate specimens can be found, even in a single locality. Ecology: cold stenothermal orophilic species living in torrents and brooks of the montane zone (900-1600 m). Flight period: autumn (IX-XI). Distribution: northwestern corner of the Iberian Peninsula (eastern Galicia, Cantabrian Cordillera, Demanda, Moncayo). New for the Sierra de la Demanda.

\section{Protonemura hispanica (Aubert, 1956)}

Material: St. 9, 11, 20, 24, 28, 36, 37, 46, 51, 57, 58, $59,61,65,66,73,81,83,84,90,94,103,108,113$ (53 males, 86 females). Ecology: widespread in different kinds of mountain water courses (220-1600 m, up to $2000 \mathrm{~m}$ in the Sierra de Guadarrama). Flight period: autumn (VIII-XII). Distribution: northwestern Iberian Peninsula.

\section{Protonemura intricata intricata (Ris, 1902)}

Material: St. 22, 28, 30, 43, 48, 49, 55, 60, 61, 63, 95, 97, 100, 102, 105, 116 (30 males, 40 females). Ecology: eurytopic mountain species, (800-1600 m, up to $2000 \mathrm{~m}$ in the Pyrenees). Flight period: spring and summer (IV-VIII). Distribution: Europe. Northern Iberian Peninsula. In the central Cordillera (Guadarrama-Estrela), it is replaced by the subspecies $P$. intricata iberiaca Zwick, 1972.

\section{Protonemura isabellae Vinçon \& Ravizza,} 1998

Material: St. 24, 29, 51, 55, 59, 61, 65 (12 males, 24 females). Ecology: cold stenothermal, orophilic species living in springs, brooks and torrents of the montane and subalpine zones (900-1700 m). Flight period: winter (II-III). Distribution: Cantabrian Cordillera. 


\section{Protonemura meyeri (Pictet, 1841)}

Material: St. 32, 44 (3 males, 1 female). Ecology: Various mountain brooks and torrents (230-1500 m, up to $2900 \mathrm{~m}$ in the Sierra Nevada). Flight period: spring (I-V). Distribution: Europe. Whole Iberian Peninsula.

\section{Protonemura navacerrada (Aubert, 1954)}

Material: St. 20, 66, 67, 80, 84, 100, 101, 109, 110, 112, 117, 118 (15 males, 18 females). Ecology: various brooks and torrents of the montane zone $(800-1600 \mathrm{~m}$, up to $2000 \mathrm{~m}$ in the Sierra de Guadarrama). Flight period: spring (II-V). Distribution: northwestern Iberian Peninsula.

\section{Protonemura praecox (Morton, 1894)}

Material: St. 22, 24, 55, 116 (7 males, 8 females). Ecology: brooks and torrents in the montane zone (100-1500 m) (Membiela 1996), up to $1700 \mathrm{~m}$ in the Pyrenees. Flight period: winter and early spring (IIIV). Distribution: Europe. Northern Iberian Peninsula: Whole Pyrenean chain, Sierra de la Demanda, Cantabrian Cordillera and Galicia (Membiela 1996, Pardo et al. 1991). New for the Sierra de la Demanda.

\section{Protonemura pyrenaica Mosely, 1930, new sta-} tus

Nemoura lacustris: Kempnyi, 1897

Nemoura (Protonemura) pyrenaica: Aubert, 1952

Protonemura pyrenaica pyrenaica: Aubert, 1963

New for the Cantabrian Cordillera. This species is separate from $P$. asturica (see previous comments on $P$. asturica). Material: St. 3, 5, 7 (3 males, 6 females). Ecology: common in various mountain brooks and torrents $(800-1300 \mathrm{~m}) ; 340-2200 \mathrm{~m}$ in the Pyrenees. Flight period: spring (III-V). Distribution: Pyrenees, Basque mountains.

\section{Protonemura risi spinulosa (Navás, 1921)}

Material: St. 1, 2, 4, 7, 16, 19, 24, 33, 48, 51, 55, 61 (60 males, 44 females). Rioja, Demanda: St. 115, 5 \$, $5 £, 4.8 .87$; $1 £, 0.11 .93$; St. 116, 33 \$, $20 £, 4.8 .87$. Ecology: rather crenophilic, living in mountain springs and brooks (600-1500 m, up to $2200 \mathrm{~m}$ in the Pyrenees). Flight period: summer (V-VIII) (-XII in the crenal). Distribution: The specimens from the southern part of the French Central-Massif: Montagne Noire (Berthélemy 1965), and Aigoual Mount (Aubert 1963), are erroneously identified. In fact they correspond better to $P$. risi risi than to $P$. risi spinulosa. Therefore, $P$. risi spinulosa is limited to the Pyrenees, Cantabrian Cordillera and Sierra de la Demanda. New for the Sierra de la Demanda.

\section{Nemoura cambrica Stephens, 1936}

Material: St. 3 (1 male). Ecology: brooks and springs, in the foothills $(100-800 \mathrm{~m})$. Flight period: spring (III-V). Distribution: Medio European and UK. In the Iberian Peninsula, it is only present in the eastern extremity of the Cantabrian Cordillera, not far from the Pyrenees. New for the Cantabrian Cordillera.

\section{Nemoura ceciliae Aubert, 1956}

Material: St. 65, 68, 69, 70, 71, 80, 100, 102, 109, 111 (16 males, 22 females). Ecology: various mountain brooks and torrents $(320-1500 \mathrm{~m})$. Flight period: spring (III-VI). Distribution: northwestern Iberian Peninsula. In the Cantabrian Cordillera, it is only present in the western part.

\section{Nemoura cinerea umbrosa Pictet, 1865}

Nemoura cinerea iberica: Zwick, 1972

Nemoura cinerea umbrosa: Zwick, 1978

Nemoura cinerea: Puig, 1984

In spite of the conclusions made by Puig 1984, and followed by several authors (Sánchez-Ortega \& AlbaTercedor 1987 and Sánchez-Ortega \& Tierno 1996), we consider $N$. cinerea umbrosa to be a valid allopatric subspecies of $N$. cinerea cinerea. The Iberian subspecies $N$. cinerea umbrosa meets $N$. cinerea cinerea in the eastern Pyrenees (Albères massif) where there are intermediate specimens between the two subspecies (Massane brook 900 m, 3 males, 2 females, 25.07.87, Moubayed leg., Sorède brook, 800 m, 1 male; 450 m, 10 male, 10 female, 25.05.93). Material: St. 2, 5, 9, $11,13,21,26,30,35,40,48,49,55,60,78,86,87,88$, 89, 100, 107, 117 (69 males, 53 females). Ecology: widespread species, living mainly in lentic biotopes (320-1680 m, up to $2400 \mathrm{~m}$ in the Sierra de Guadarrama). Flight period: spring and summer (III-VIII). Distribution: Iberian Peninsula.

\section{Nemoura lacustris Pictet, 1865}

Material: St. 110 (18 males, 21 females). Ecology: living in lentic mountain biotopes (600-850 m), up to $1800 \mathrm{~m}$ in the Sierra de Guadarrama (Aubert 1956). Flight period: spring (III-V). Distribution: Iberian Peninsula, southern France and North Africa.

\section{Nemoura moselyi Despax, 1934}

Material: St. 1, 2, 4, 7, 9, 14, 18, 19, 21, 23, 26, 30, 34, 36, 40, 41, 49, 51, 54, 55, 58, 61, 63, 115, $116(113$ males, 74 females). Ecology: cold stenothermal, orophilic species, living in springs and brooks (600-1600 $\mathrm{m}$, up to $2300 \mathrm{~m}$ in the Pyrenees). Flight period: spring 
and summer (IV-VIII) (-XI in the crenal). Distribution: Pyrenees, Cantabrian Cordillera and Sierra de la Demanda. New for the Sierra de la Demanda.

\section{Nemoura pseudoerratica Vinçon \& Pardo, 2003}

Previous mentions of $N$. erratica in the Iberian Peninsula correspond to $N$. pseudoerratica Vinçon \& Pardo, 2003. Material: St. 5, 7, 9, 10, 13, 14, 18, 19, 40, 56, 112, 113, 115, 116 (61 males, 38 females). Ecology: cold stenothermal, orophilic species, living in springs and brooks (800-1450 $\mathrm{m}$, up to $2400 \mathrm{~m}$ in the Pyrenees). Flight period: spring (III-VI). Distribution: Pyrenees, Cantabrian Cordillera, Demanda, Cameros.

\section{Nemoura uncinata Despax, 1934}

Material: St. 50 (1 male, 3 females). Ecology: various mountain water courses (400-1300 m, up to 2100 $\mathrm{m}$ in the Pyrenees). Flight period: spring (IV). Distribution: Europe. Northern half of the Iberian Peninsula.

\section{Nemoura xistralensis Vinçon \& Pardo, 2003}

Material: St. 55, 61, 65, 74, 75 (12 males, 15 females). Ecology: cold stenothermal species, living in mountain springs and brooks (500-1500 m). Flight period: late spring (VI). Distribution: northern Galicia and western Cantabrian Cordillera.

\section{Capnia nigra (Pictet, 1833)}

Material: St. 22, 61 (5 males, 4 females). Ecology: slow mountain rivers and brooks (700-1300 m, up to $2160 \mathrm{~m}$ in the Sierra Nevada, where the adults are micropterous). Flight period: early spring (III-IV). Distribution: Palearctic. Whole Iberian Peninsula. Very scarce in the Cantabrian Cordillera.

\section{Capnioneura brachyptera Despax, 1932}

Material: St. 61 (3 males, 3 females). Ecology: cold stenothermal, strongly crenophilic, restricted to the headwater of brooks near to their source (1000-1300 $\mathrm{m}$, up to $2200 \mathrm{~m}$ in the Pyrenees). Flight period: autumn (X-XI). Distribution: Pyrenees and Cantabrian Cordillera where it is known from only one locality in western Asturias, very far from the Pyrenees.

\section{Capnioneura libera Navás, 1909}

Material: St. 4, 6, 7, 9, 10, 19, 21, 23, 24, 31, 35, 37, $45,50,53,56,66,68,69,71,80,81,82,84,85,108$, 109, 110, 111, 112, 113, 114, 115, 118 (75 males, 119 females). Ecology: widespread in the whole Cantabrian Cordillera where it lives in various kinds of wa- tercourses (450-1600 m, up to $1900 \mathrm{~m}$ in the Sierra de Candelario). Flight period: winter (XI-V). Distribution: endemic to the Iberian Peninsula and western Pyrenees. Its spatial distribution covers the whole Peninsula except near the Mediterranean (Berthélemy \& Whytton da Terra 1980; Tierno de Figueroa et al. 1997; Vinçon \& Sánchez-Ortega 2002).

\section{Capnioneura mitis Despax, 1932}

Material: St. 1, 4, 5, 7, 9, 14, 93, 95, 109, 110 (4 males, 28 females). Ecology: in the Cantabrian Cordillera and Pyrenees, it lives mainly in the foothills (450-1100 m), but it is more orophilic in southern Spain where it reaches $2400 \mathrm{~m}$ in the Sierra Nevada. Flight period: spring (I-V). Distribution: western Europe. Whole Iberian Peninsula.

\section{Capnioneura narcea Vinçon \& Sánchez -Orte- ga, 2002}

Material: St. 64, 65, 70, 71 (28 males, 32 females). Ecology: strongly crenophilic species, living in springs and very small brooklets (900-1500 m). Flight period: winter (XI-II + VI in the crenal). Distribution: western Cantabrian Cordillera.

\section{Leuctra alosi Navás, 1919}

Morphological notes: in the surroundings of the Picos de Europa, the variability of this species is very high with numerous males having two tiny sharp sclerotized processes on tergite VIII. These spiny processes are placed on the corners of the lateral edges and the anterior margin. Some specimens have just one spiny process, other specimens have no spiny processes at all. This form could be described as a subspecies of $L$. alosi but we did not consider it useful since the variability of the specimens is very high. Material: St. 2, 7, 9, 18, 19, 21, 22, 23, 28, 30, 34, 36, 40, 41, 43, $45,47,48,49,50,51,54,55,58,59,60,61,62,63,65$, $68,71,72,77,79,86,87,100,102,107,111,115,116$ (242 males, 333 females). Ecology: widespread in various kinds of mountain water courses (450-1680 m, up to $2400 \mathrm{~m}$ in the Pyrenees). Flight period: spring and summer (IV-VIII). Distribution: northern half of the Iberian Peninsula, Pyrenees.

\section{Leuctra auriensis Membiela, 1989}

Material: St. 62, 69, 84, 102, 103 (12 males, 26 females). Ecology: eurytopic species living in various kinds of watercourses except the largest rivers (220$1600 \mathrm{~m}$ ). Flight period: autumn (VIII-IX). Distribution: Galicia, western Cantabrian Cordillera. New for the Cantabrian Cordillera. 


\section{Leuctra aurita Navás, 1919}

Material: St. 7, 21, 22, 23, 24, 28, 34, 48, 49, 51, 54, 55, 59, 61, 81, 118 (57 males, 75 females). Ecology: orophilic species living in mountain brooks and torrents (850-1600 $\mathrm{m}$, up to $2300 \mathrm{~m}$ in the Pyrenees). Flight period: autumn (VIII-X + XII in the crenal). Distribution: Middle Europe.

\section{Leuctra besucheti Aubert, 1962}

Material: St. 62, 63, 64, 69, 71 (168 males, 153 females). Ecology: cold stenothermal, crenophilic species living in mountain sources and brooklets (850$1100 \mathrm{~m}$ ). Flight period: autumn and winter (IX-IV, throughout the year in the crenal). Distribution: Galicia and western Cantabrian Cordillera. The supposed presence of this species in the Sierra de Gudar (Aubert 1963 ) is erroneous. The unique female collected in this region is very different from that of $L$. besucheti and could correspond to that of L. balearica.

\section{Leuctra castillana Aubert, 1956}

Material: St. 6, 7, 9, 17, 18, 20, 21, 22, 23, 24, 36, $42,46,61,66,73,81,82,83,90,91,92,95,102,103$, 104, 105, 108, 114, 117, 118 (359 males, 253 females). Ecology: eurytopic, living mainly in the foothills rivers and brooks (100-1550 m, up to $1900 \mathrm{~m}$ in the Pyrenees). Flight period: autumn (VIII-XII). Distribution: northern Iberian Peninsula, Pyrenees, French Massif-Central.

\section{Leuctra despaxi Mosely, 1930}

Material: St. 34, 38 (1 male, 1 female). Ecology: cold stenothermal, orophilic, crenophilic species, (1100-1200 m, up to $2000 \mathrm{~m}$ in the Pyrenees). It lives mainly in the calcarous regions where we found it abundantly near the sources and some specimens were even captured in the caves. Flight period: spring (IVVIII). Distribution: northwestern Iberian Peninsula, Pyrenees, French Massif-Central.

\section{Leuctra espanoli Aubert, 1956}

Material: St. 9, 13, 16, 21, 22, 24, 25, 28, 35, 36, 39, $40,42,46,51,53,57,59,61,65,66,72,73,81,115$ (160 males, 136 females). Ecology: cold stenothermal, orophilic, crenophilic species (850-2000 m). Flight period: late autumn (IX-XII + II). Distribution: northwestern corner of the Iberian Peninsula (eastern Galicia, Cantabrian Cordillera, Demanda, western Pyrenees). New for the Sierra de la Demanda and Galicia.

\section{Leuctra franzi franzi Aubert, 1956}

Material: St. 69, 73, 91, 95, 102, 103, 104, 105 (27 males, 20 females). Ecology: brooks and rivers, chie- fly in the foothills (80-1200 $\mathrm{m}$, up to $1600 \mathrm{~m}$ in the Sierra de Gudar). Flight period: autumn (VII-X). Distribution: northern Iberian Peninsula. In Andalucia and the Morrocan Rif, it is replaced by L. franzi paenibaetica Sánchez-Ortega \& Ropero-Montero, 1993.

\section{Leuctra fusca fusca (Linné, 1758)}

Material: St. 6, 11, 18, 22, 39, 42, 61, 73, 81, 92, 114 (38 males, 57 females). Ecology: eurytopic species, widespread in mountain and foothill water courses (150-1300 m, up to $2890 \mathrm{~m}$ in the Sierra Nevada). Flight period: late autumn (IX-II). Distribution: Europe, Asia. Whole Iberian Peninsula.

\section{Leuctra gallaeca Membiela, 1989}

Material: St. 84, 94, 107 (37 males, 34 females). Ecology: orophilic, crenophilic species living in high mountain brooks and sources (1100-1600 m). Flight period: late autumn (IX-XII). Distribution: southern Galicia (Invernadeiro and Manzaneda mountains).

\section{Leuctra geniculata Stephens, 1836}

Material: St. 6, 73 (3 males, 8 females). Ecology: living in large water courses of the foothills (150-950 $\mathrm{m})$. The higher altitudinal limit in the Iberian Peninsula is $1400 \mathrm{~m}$ in Sierra de Huétor (Granada) (Luzón-Ortega et al., 1998). Flight period: autumn (IX-XII). Distribution: western Europe, Maghreb.

\section{Leuctra hiberiaca Aubert, 1956}

Material: St. 92, 94 (5 males, 9 females). Ecology: orophilic species living in brooks and torrents (900$1420 \mathrm{~m}$, up to $2000 \mathrm{~m}$ in the Sierra de Guadarrama). Flight period: autumn (IX-XI). Distribution: Iberian Central Cordillera (Guadarrama-Estrela); it reaches the southern extremity of Galicia, near the Portuguese Border.

\section{Leuctra hippopus Kempny, 1898}

Material: St. 1, 3, 7, 9, 10, 11, 13, 14, 16, 22, 28, 37, 43, 50, 51, 60, 61, 67, 73, 80, 103, 113, 118 (110 males, 102 females). Ecology: eurytopic species, widespread chiefly in the lower water courses (80-1600 m, up to $1900 \mathrm{~m}$ in the Pyrenees). Flight period: spring (II-VI). Distribution: Europe, Anatolia, Caucasus. Northern half of the Iberian Peninsula. New for the Sierra de la Demanda and Sierra del Moncayo.

\section{Leuctra hispanica Aubert, 1952}

Material: St. 22, 23, 24, 53, 59, 61, 81, 115, 116, 118 (17 males, 40 females). Ecology: orophilic species living in various kinds of mountain water courses (900-1600 m, up to $2000 \mathrm{~m}$ in the Sierra de Guadarra- 
ma). Flight period: autumn (IX-XI). Distribution: northern half of the Iberian Peninsula.

\section{Leuctra inermis Kempny, 1899}

Material: St. 7, 11, 16, 21, 22, 23, 26, 28, 31, 34, 37, $38,43,44,51,52,57,59,60,61,65,73,80,84,89$, 100, 101, 112, 115, 116, 117 (159 males, 161 females). Ecology: eurytopic species, widespread in various kinds of mountain water courses (800-1600 m, up to $2950 \mathrm{~m}$ in the Sierra Nevada). Flight period: spring (II$\mathrm{VIII}+\mathrm{X}$ in the crenal). Distribution: Europe. Whole Iberian Peninsula.

\section{Leuctra kempnyi Mosely, 1932}

Material: St. 1, 2, 3, 4, 5, 7, 8, 9, 14 (76 males, 86 females). Ecology: cold stenothermal, strongly crenophilic species, living in mountain sources and brooklets (600-1100 m, up to $1750 \mathrm{~m}$ in the Pyrenees). Flight period: spring (III-VII). Distribution: western Pyrenees, eastern Cantabrian Cordillera. New for the Cantabrian Cordillera.

64. Leuctra lamellosa lamellosa Despax, 1929, new status

Morphological remark: the specimens of L. lamello$s a$ collected in the surroundings of the Somiedo valley (western Cantabrian Cordillera), are intermediate forms between L. lamellosa and L. lusitanica, suggesting that these two taxa belong to the same species. Consequently, L. lusitanica is considered an allopatric subspecies of L. lamellosa. Material: St. 2, 4, 6, 7, 9, $16,19,20,21,23,24,25,28,34,35,36,39,40,42$, 48, $51,53,54,55,56,57,59,61,65,72,115,116$ (339 males, 300 females). Ecology: widespread in the mountain water courses (700-2000 m, up to $2200 \mathrm{~m}$ in the Pyrenees). Flight period: summer and autumn (VII-XII). Distribution: Pyrenees, Cantabrian Cordillera, Demanda.

65. Leuctra lamellosa lusitanica Aubert, 1962, new status

This taxa is considered as a subspecies of L. lamellosa (see foregoing morphological remarks on L. lamellosa lamellosa). Material: St. 62, 63, 64, 65, 66, $71,81,83,84,90,91,92,94,103,104,105$ (85 males, 90 females). Ecology: Various kinds of mountain water courses (120-1600 m). Flight period: autumn (VIII$\mathrm{XII}+\mathrm{VI}$ in the crenal). Distribution: Lusitanian species (from Portugal to Galicia). New for the Cantabrian Cordillera.

\section{Leuctra madritensis Aubert, 1952}

Material: St. 9, 16, 18, 20, 22, 23, 24, 28, 34, 46, 53 , $59,61,67,72,73,81,83,91,92,94,95,102,103,104$,
105, 116, 118 (314 males, 201 females). Ecology: orophilic species, living in mountain brooks and torrents (80-1600 m, up to $2000 \mathrm{~m}$ in the Sierra de Guadarrama). Flight period: autumn (VIII-II). Distribution: northern half of the Iberian Peninsula.

\section{Leuctra maroccana Aubert, 1956}

Material: St. 6, 7, 9, 21, 23, 26, 29, 32, 36, 40, 44, $51,55,56,59,61,66,73,85,109,113,114,118(55$ males, 39 females). Ecology: crenophilic species, living in mountain and foothill brooks and sources (80$1700 \mathrm{~m}$, up to $2000 \mathrm{~m}$ in the Sierra Nevada). Flight period: winter (XI-III + V in the crenal). Distribution: Maghreb, Iberian Peninsula, western Pyrenees. New for the Cantabrian Cordillera, Sierra de la Demanda and Sierra del Moncayo.

68. Leuctra microstyla microstyla Vinçon \& Ravizza, 2000

Material: St. 35, 36, 51, 52 (52 males, 58 females). Ecology: cold stenothermal, strongly crenophilic species (1000-1200 m). Flight period: winter (XI-IV + VI in the crenal). Distribution: middle part of the Cantabrian Cordillera, in the surroundings of the Sella Valley.

\section{Leuctra microstyla nalon Vinçon \& Ravizza, 2000}

Material: St. 37, 39, 40, 41, 42, 45, 55, 56, 59, 60 (142 males, 109 females). Ecology: cold stenothermal, strongly crenophilic species (800-1450 m). Flight period: winter and spring (XI-VI). Distribution: western Cantabrian Cordillera.

\section{Leuctra microstyla saja Vinçon \& Ravizza, 2000}

Material: 21 (15 males, 8 females). Ecology: cold stenothermal, strongly crenophilic species $(1200 \mathrm{~m})$. Flight period: spring (III-VI). Distribution: eastern Cantabrian Cordillera.

\section{Leuctra pseudocylindrica Despax, 1929}

Material: St. 2, 3, 4 (20 males, 10 females). Ecology: crenophilic species, living in mountain springs and brooks (700-1000 m, up to $1775 \mathrm{~m}$ in the Pyrenees). Flight period: autumn (VII-III). Distribution: Pyrenees, Basque mountains. New for the Cantabrian Cordillera.

\section{Leuctra stupeningi Illies, 1954}

Material: St. 62, 66, 67, 75, 76, 80, 81, 82, 83, 84 85, 100, 101, 109 (64 males, 54 females). Ecology: crenophilic species, living in mountain springs and 
brooks (350-1600 m, up to $1900 \mathrm{~m}$ in the Sierra de Candelario). Flight period: winter (XI-III). Distribution: northwestern Iberian Peninsula. Western Cantabrian Cordillera. New for the Cantabrian Cordillera.

\section{Leuctra wilmae Illies, 1954}

Material: St. 9, 12, 18, 19 (75 males, 71 females). Ecology: cold stenothermal, strongly crenophilic species living in mountain springs and brooks (800-1400 $\mathrm{m})$. Flight period: winter (XI-IV). Distribution: eastern Cantabrian Cordillera.

\section{Stonefly diversity}

In the more recent inventories of Iberian stoneflies, 57 species have been mentioned from the Cantabrian Cordillera (Sánchez-Ortega \& Alba-Tercedor 1987, Sánchez-Ortega \& Tierno 1996). This list needs to be complemented with the following 27 species:

- 13 species that were described or mentioned within the last six years: Protonemura brittaini, $P$. fusunae, $P$. isabellae (Vinçon \& Ravizza 1998), Rhabdiopteryx antoninoi (Vinçon \& Ravizza 1999), Leuctra besucheti, L. microstyla microstyla, L. microstyla nalon and $L$. microstyla saja (Vinçon \& Ravizza 2001), Capnioneura brachyptera, $C$. libera, $C$. narcea (Vinçon \& Sánchez-Ortega 2002), Nemoura pseudoerratica, N. xistralensis (Vinçon \& Pardo 2003).

- 14 species that are recorded for the first time in the Cantabrian Cordillera (Tab. 1): Isoperla sp. 3, Isoperla sp. d, I. viridinervis, Chloroperla nevada, Amphinemura guadarramensis, Protonemura globosa, P. pyrenaica, Nemoura cambrica, Leuctra auriensis, L. kempnyi, L. lamellosa lusitanica, L. maroccana, L. pseudocylindrica and L. stupeningi.

Two species reported previously from the Cantabrian Cordillera are suppressed in our revised list:

- L. illiesi: a single female specimen is reported from Asturias (Aubert 1956, 1963). However, it probably belongs to L. microstyla nalon whose female is very similar to that of L. illiesi.

- L. leptogaster: in the Iberian Peninsula, adults of $L$. leptogaster are only reported from the Pyrenees. Its presence in Asturias (Puig-Garcia et al. 1984) is doubtful and should be confirmed by captures of adults.

Therefore the total number of Cantabrian stoneflies comprises 82 species (Table 1). Moreover, 3 species are added to the stonefly fauna of Galicia: Protonemura fusunae (Vinçon \& Ravizza 1998), Nemoura xistralensis (Vinçon \& Pardo 2003) and Leuctra espanoli (new record), whereas 6 species erroneously reported from Galicia should be suppressed: Brachyptera seticornis, Guadalgenus franzi, Hemimelaena flaviventris, Brachyptera monilicornis, Rhabdiopteryx thienemanni and Leuctra illiesi (Sánchez-Ortega \& Tierno 1996). The first one does not extend southwards from the Pyrenean chain, while the others extend up to central or northern Portugal (Zwick 1972, Whytton da Terra 1979, Berthélemy \& Whytton da Terra 1980).

Revision of the Protonemura intricata material from Galicia showed that these specimens were misidentified as $P$. intricata iberiaca (in Membiela Iglesia 1996); in fact they belong to $P$. intricata intricata. Therefore, we assume that $P$. intricata iberiaca is restricted to the Central Cordillera (Spain) and Serra da Estrela (Portugal), and we exclude this species from the Galician Fauna. Consequently, the total number of Galician stoneflies comprises 56 species (Table 1).

Finally, 9 species are added to the fauna of the Sierra de la Demanda: Brachyptera risi, Protonemura asturica, $P$. hiberiaca, $P$. praecox, $P$. risi spinulosa, $\mathrm{Ne}$ moura moselyi, Leuctra espanoli, L. hippopus, L. maroccana, and 2 are added to the fauna of the Sierra del Moncayo: L. hippopus and L. maroccana.

\section{Stonefly distribution}

Several species groups of stoneflies may be distinguished in the northwestern part of the Iberian peninsula in relation to their spatial distribution (Table 1). They are listed from West to East.

\section{Lusitanian microendemic species ( 3 species)}

These species occupy a restricted geographical area along the northwestern coast of the Iberian Peninsula: Chloroperla acuta is restricted to the Galaico-Portuguese mountains; Protonemura globosa and Leuctra lamellosa lusitanica occupy Galicia and northern Portugal.

\section{Cantabrian and Galician endemic species (15 sp.)}

The Cantabrian Cordillera and the Galician mountains have a rich endemic fauna composed of 16 species and subspecies. Some are distributed over large areas (macroendemics), while others are localized in very restricted areas (microendemics). Based on our data and on literature, the following six groups of micro and macroendemic species may be distinguished:

- Galician microendemic species (2 sp.): Amphinemura hibernatarii and Leuctra gallaeca. 
- Galician and West Cantabrian microendemic species (4 sp.): Protonemura fusunae, Nemoura xistralensis, Leuctra auriensis and L. besucheti.

- West Cantabrian microendemic species (2 sp.): Capnioneura narcea and Leuctra microstyla nalon.

- Medio Cantabrian microendemic species (1 sp.): Leuctra microstyla microstyla.

- East Cantabrian microendemic species (3 sp.): Protonemura brittaini, Leuctra microstyla saja and Leuctra wilmae.

- Cantabrian macroendemic species (distributed over most of the Cantabrian Cordillera) (3 sp.): Isoperla acicularis cantabrica, Rhabdiopteryx antoninoi and Protonemura isabellae.

\section{Widely distributed Cantabrian species (2 sp.)}

The distribution area of Protonemura hiberiaca and Leuctra espanoli mainly covers the whole Cantabrian Cordillera and extends in eastern Galicia and in the western part of the Iberic system, northwards the Duero River (Demanda-Cameros or Moncayo). The latter species also extends in the western extremity of the Pyrenees.

\section{Pyreneo-cantabrian species (7 sp.)}

This distribution area covers both the Pyrenees and the Cantabrian Cordillera. Some species are distributed throughout the entire Cantabrian Cordillera, while others are restricted to the eastern part. Consequently, we distinguish the two following groups:

- Pyrenean species widely distributed in the eastern part of the Cantabrian Cordillera (4 sp.): Isoperla viridinervis, Protonemura pyrenaica, Leuctra kempnyi and L. pseudocylindrica.

- Pyreneo-Cantabrian species covering the whole Cantabrian Cordillera (3 sp.): Isoperla sp. d, Chloroperla breviata, and Capnioneura brachyptera. The case of $C$. brachyptera is special because this species, widespread in the highest part of the Pyrenees, is known from only one locality in the western part of the Cantabrian Cordillera, far away from the Pyrenees. The Cantabrian specimens differ slightly from the Pyrenean ones, suggesting geographical isolation of this Cantabrian population (Vinçon \& Sánchez-Ortega 2002).

Pyreneo-cantabrian species extending into the Demanda - Cameros massif (4 sp.)

This distribution covers the whole Pyrenean and Cantabrian chain and extends into the northwestern part of the Iberic system that is close to the Pyrenees
(Demanda - Cameros massif): Protonemura risi spinulosa, Nemoura moselyi, N. pseudoerratica and Leuctra lamellosa lamellosa.

\section{North Iberian species (12 sp.)}

The distribution area extends from the Cantabrian Cordillera to the Sierra de Guadarrama: Brachyptera arcuata, Protonemura asturica, $P$. hiberiaca, P. hispanica, P. navacerrada, Nemoura ceciliae, Leuctra alosi, L. franzi franzi, L. hiberiaca, L. hispanica, L. madritensis and L. stupeningi. Only L. alosi is found also in the Pyrenees. L. franzi franzi is also present in Algarve (southern Portugal) but it is replaced by L. franzi paenibaetica in Andalucia and North Africa.

\section{Iberian species ( $7 \mathrm{sp}$.)}

These species have a wide distribution area in the Iberian Peninsula: Isoperla bipartita, I. curtata, Perla madritensis, Chloroperla nevada, Amphinemura guadarramensis, Nemoura cinerea umbrosa and Capnioneura libera.

\section{Iberian and North African species (2 sp.)}

$H$. flaviventris and L. maroccana. The former species extends from North Africa up to the southern slope of the Cantabrian Cordillera. The latter is more widely distributed, reaching the western Pyrenees.

\section{Species distributed in western Europe (11 sp.)}

Isoperla sp. 3, Marthamea selysii, Perla bipunctata, Rhabdiopteryx thienemanni, Protonemura beatensis, Nemoura fulviceps, N. lacustris, Capnioneura mitis, Leuctra castillana, L. despaxi and L. geniculata. N. lacustris and L. geniculata also occur in North Africa.

\section{Species with wide distribution in Europe ( 29 sp.)}

These species are widespread in Europe and some extend into Asia, the Palearctic region or are even Holarctic: Arcynopteryx compacta (Holarctic), Perlodes dispar, P. microcephalus, Isoperla grammatica, Dinocras cephalotes, Perla burmeisteriana, Pe. grandis, Pe. marginata, Chloroperla tripunctata, Siphonoperla torrentium, Taeniopteryx schoenemundi, Brachyptera braueri, B. monilicornis, B. risi, Amphinemura sulcicollis, A. triangularis, Protonemura intricata intricata, P. meyeri, P. praecox, Nemoura cambrica, N. uncinata, Nemurella pictetii, Capnia bifrons, C. nigra, Leuctra aurita, L. fusca fusca, L. hippopus, L. inermis and L. major.

The stonefly fauna of the Galaico-Portuguese mountains is well diversified, especially in northern Galicia (49 species, $18.4 \%$ microendemics) and sou- 
thern Galicia: (42 species, $16.7 \%$ ). The Cabrera - Teleno massif appears much poorer (37 species, $5.4 \%$ ). Along the Cantabrian Cordillera, the number of species and the rate of microendemism are very variable (Tab. 1): the richest area corresponds to the western part of the Cordillera, having the highest number of species $(57 \mathrm{sp}$.) and the highest rate of microendemism $(19.3 \%)$. The second richest area corresponds to the central part (55 sp., $9.1 \%$ of microendemism), and then the eastern part (54 sp., $11.1 \%$ ). The Basque Country between the Cantabrian Cordillera and the Pyrenees is very poor in species (26 sp.), probably due to the lower altitudes that characterize this region. The richness of the Demanda - Cameros massif (42 sp., no microendemics) is intermediate between those of the two neighbouring regions: eastern Cantabrian Cordillera, and Basque Mountains. The reduction of richness and microendemism compared to the eastern Cantabrian Cordillera could be linked to the drier climate. Indeed, in the Iberian Peninsula and Pyrenees a high level of microendemism is found in the more humid regions (western Pyrenees, northern slopes of the Cantabrian Cordillera, Galician and Lusitanian mountains).

Though the Cantabrian Cordillera and the Pyrenees are similar in geographical extension, and are subject to the same humid Atlantic climate (except the oriental part of the Pyrenees under a clear Mediterranean climatic influence), the stonefly diversity is somewhat lower in the Cantabrian Cordillera (82 taxa including 15 microendemic species) than in the Pyrenees (98 taxa including 19 microendemic species). This difference may be explained by the much higher altitude of the Pyrenees (3400 m) compared with the Cantabrian Cordillera $(2600 \mathrm{~m})$. This allows a greater diversity of high-mountain aquatic biotopes where several strongly orophilic species live almost exclusively above 1800 m: Protonemura culmenis, P. tuberculata, Pachyleuctra bertrandi, Leuctra alticola, L. ariega and L. thomasi. The higher altitudes of the Pyrenees also favour orophilic isolation. The Pyrenean Plecoptera fauna is also enriched by its closer connection to the rest of Europe.

\section{Biogeography}

The following abbreviations are used in this paragraph and in figures $2 \mathrm{a}, 2 \mathrm{~b}$ : $\mathrm{CC}=$ Cantabrian Cordillera, $\mathrm{N}=$ North, $\mathrm{S}=$ South. The classification analysis (Fig. 2a) distinguishes two main groups and an isolated element (Basque Mountains). The first group mainly corresponds to the Galaico-Portuguese Mountains, inclu- ding the western Cantabrian Cordillera (West CC). Within the second group, the fauna of two regions of the genuine Orocantabric high mountains (Central CC and East CC) show high similarity, and show lower similarity with the Demanda-Cameros and Pyrenees stonefly fauna. The Basque mountains, characterized by an impoverished Plecoptera fauna, are separated from both main groups at the minimum similarity level (Fig 2a). A distinct spatial distribution from Portugal and Galicia towards the Cantabrian Cordillera and the Pyrenees appears along axis I in the ordination plot (Fig. 2b). The East-West faunistic gradient of change in species composition corresponds to the present biogeographic sectorisation. The value of the axis is indicated by its high variance, $73.6 \%$ of total variance explained by the first four axes. On this axis, West $\mathrm{CC}$ holds an intermediate position between Galicia and the group: Central CC + East CC + Demanda-Cameros mountains; indeed, its fauna has a high number of microendemic species in common with Galicia (P. fusunae, $N$. xistralensis, Cn. narcea, L. auriensis, L. besucheti). Moreover, it includes Iberian species not represented in the Central and East CC (Ch. nevada, P. globosa, $N$. ceciliae, L. franzi franzi, L. lamellosa lusitanica, $L$. stupeningi). Moreover, the differences between the fauna of West CC and East CC may be explained by the main geographic barrier, created by the high elevation $(2600 \mathrm{~m})$ and the calcareous bedrock of the huge massif of the Picos de Europa.

Axis II of the ordination separates Portugal from $\mathrm{S}$ and $\mathrm{N}$ Galicia, in agreement with latitudinal faunistic changes from South to North. Although highly similar, the observed differences between the fauna of these two regions may be explained by the geographic barrier created by the Miño-Sil rivers valley. Few endemic species are only present in the southern part of Galicia (L. hiberiaca, L. gallaeca) and others are only present in the northern part (P. fusunae, N. xistralensis, L. besucheti). The fauna of the Basque Mountains represents a subset of the larger fauna found in the Pyrenees, indicated by their relative position along axis I. The Basque Mountains have a significantly less diversified fauna than the rest of the Pyrenees.

The distribution obtained in this analysis is in agreement with the bioclimatic and biogeographic knowledge of the northern Iberian Peninsula. In the climatic and vegetation analyses, 4 mountainous sectors can be distinguished: the Galaico-Portuguese mountains, the Cantabrian Cordillera, the Basque mountains and the Pyrenees (Peinado \& Rivas-Martínez 1987; Ramil-Rego et al. 1988 a, b). The Galaico-Portuguese mountains include several mountainous units of lower altitu- 
de and high oceanic character, interconnected by wide sedimentary basins and stream valleys. These conditions have favoured the development of deciduous forests, which during the warmer periods of the Holocene colonized higher altitude areas. The higher altitudes and greater climatic contrast of the Cantabric and Pyrenean mountains have favoured, during the last Quaternary periods, the development of mixed forests, predominantly deciduous elements with evergreens, although dominated by Pinus and Juniperus in the more continental parts. The forests did not reach the highest mountainous areas and even in the warmest periods of the Holocene, a very large area remained above the tree line.

The transition in the Galaico-Portuguese mountains is very diffuse, whereas greater heterogeneity is found between the Basque mountains and the Cantabric and Pyrenean mountains. This heterogeneity may be explained by geographical conditions: the Cenozoic depression of the Ebro River interspersed between the two areas, a high altitude area with flat morphology, which in this transition area promotes a more continental character, and an old and hierarchical stream network deeply incised in the Cenozoic sediments.

The Plecoptera fauna is characterized by a high number of species relying on allochtonous organic matter, inhabiting cold forested streams and rivers due to their cold stenothermal preferences. In the GalaicoPortuguese mountains, plecopteran species inhabiting lowland streams during the last glacial period would follow the vegetation expansion towards upstream reaches in the post-glacial period, favoured also by the colder temperatures. This may explain the wider altitudinal range of distribution for the Galician and Portuguese microendemic species, where speciation occurs from lowland towards upstream areas. The higher altitudinal range of distribution of micro and macroendemic species in the Cantabric mountains and the Pyrenees, may be attributed to the same processes of species dispersion and speciation after glacial periods. However, in this case, higher altitude and the existence of refuges may have promoted higher altitude speciation. The relatively low richness found in the Basque mountains may be attributed to its transitional character between both Cantabrica and the Pyrenees, to its lower altitudes and greater degree of human disturbance.

\section{Acknowledgements}

We express our gratitude to Asger Meulengracht Olsen, Manuel Molles, José Manuel Tierno de Figueroa, Jean Paul Reding, John Brittain, Pablo Ramil-Rego and Peter Zwick for reviewing the manuscript and for their valuable comments. The Galician part of this study was sponsored partially by the grant 1FD97-1481-C02.
}

\section{References}

Aubert J. 1948. — Plécoptères décrits par le R.P. L. Navás S.J. $1^{\circ}$ note: note sur quelques types du Musée de Barcelone. Bul. Soc. ent. Suisse, 21, 180-184.

Aubert J. 1954. - Quelques Nemuridae espagnols nouveaux. Mitt. Schweiz. Ent. Ges., 27, 115-123.

Aubert J. 1956. - Contribution à l'étude des Plécoptères d'Espagne. Mem. Soc. vaudoise Sc. nat., 1, 209-276.

Aubert J. 1962. — Quelques Leuctra nouvelles pour l'Europe (Plécoptères Leuctridae). Mitt. Schweiz. ent. Ges., 35, 55-69.

Aubert J. 1963. — Les Plécoptères de la Péninsule Ibérique. Eos, 39 23-107.

Berthélemy C. 1965. - Note faunistique sur les Plécoptères du Massif Central. Ann. Limnol., 2, 221-237.

Berthélemy C. 1966. - Recherches écologiques et biogéographiques sur les Plécoptères et Coléoptères d'eau courante (Hydraenae et Elminthidae) des Pyrénées. Ann. Limnol., 2, 227-458.

Berthélemy C. 1979. — Mating calls and taxonomy in Pyrenean Isoperla. Gewäss. Abwäss., 64, 71-72.

Berthélemy C. \& González del Tánago M. 1983. — Les Taeniopterygidae du bassin du Duero (Insecta: Plecoptera). Ann. Limnol., 19, 9-16.

Berthélemy C. \& Whytton da Terra L. 1980. — Plécoptères du Portugal (Insecta). Ann. Limnol., 16, 159-182.

González del Tánago M. 1984. — Distribution of Plecoptera in the Duero basin (Spain). Ann. Limnol., 20, 49-56.

Illies J. 1954. - Zwei neue Arten des Plecopterengattung Leuctra aus Spanien. Mitt. Schweiz. ent. Ges., 27, 410-412.

Luzón-Ortega J.M., Tierno de Figueroa J. M. \& Sánchez-Ortega A. 1998. - Faunistic and phenology of Stoneflies (Insecta, Plecoptera) from Sierra de Huetor (Granada, Spain) and their relationship with other areas of the Iberian Peninsula and North Africa. Zool. Baetica, 9, 91-106.

Membiela Iglesia P. 1989. - Two new species of Leuctra of the Iberian Peninsula (Insecta, Plecoptera). Aquat. Insects, 11, 81-87.

Membiela Iglesia P. 1990. — Contribución al conocimiento faunístico de los Plecópteros de Galicia (Plecoptera). Bol. Asoc. esp. Entom., 14, 89-103.

Membiela Iglesia P. 1996. — Inventario de los Plecópteros de Galicia (Insecta: Plecoptera). Cadernos da área de Ciencias Biolóxicas (Inventarios). Seminario de Estudos Galegos, Vol. XIII. O. Castro-Sada. A Coruña. Ed. Do Castro, 33 pp.

Navás L. 1901. — Notas Neuropterológicas. IV. Pérlidos de España. Bull. Inst. catal. Hist. nat., 1, 46-50.

Navás L. 1908. - Neurópteros de España y Portugal. Broteria, 6 , 218-231.

Navás L. 1915. - Excursiones por el norte de España. Asoc. Esp. Progr. Cienc., Congreso de Valladolid, 161-179.

Navás L. 1917. - Neurópteros nuevos o poco conocidos. (9 serie). Mems. R. Acad. Cienc. Artes Barcelona., 13, 395-398.

Pardo I. 1989. - New data on the genus Amphinemura Ris (Plecoptera: Nemouridae) from the Iberian Peninsula, with description of a new species. Aquat. insects, 11, 209-216.

Pardo I. 1992. - Estudio comparado de la macrofauna bentónica (ambientes lóticos) de los ríos Louro y Tea (Pontevedra). Thesis doctoral. Universidad de Santiago de Compostela. 443 pp.

Pardo I., Eiroa E. \& Novoa F. 1991. — Contribution to the Stonefly Fauna of Galicia. Pages 325-327 in Alba-Tercedor J. \& SánchezOrtega A. (Eds). Overview and Strategies of Ephemeroptera and Plecoptera. Sandhill Crane Press, Gainsville.

Peinado M. \& Rivas-Martínez S. 1987. — La vegetación de España. Servicio de Publicaciones Universidad de Alcalá de Henares. $544 \mathrm{pp}$. 
Presa Y., Luis E., Soto J. \& Postigo M. 1990. — Caracterización de la fauna de macroinvertebrados bentónicos en la cuenca del River Orbigo (León). Scientia gerundensis, 16, 195-202.

Puig-Garcia M.A., González G. \& Soriano O. 1984. — Introducción al estudio de las comunidades macrobentonicas de los Rivers asturianos: Efemeropteros, Plecópteros, Tricópteros, Simulidos y Quirinómidos. Limnetica, 1, 188-196.

Puig-Garcia M.A., 1985. - The spanish subspecies of Nemoura cinerea (Retzius) (Plecoptera, Nemouridae). Bolm. Soc. port. Ent., Supl. 1, 2, 445-451.

Ramil-Rego P., Rodríguez-Guitián M.A. \& Muñoz-Sobrino C. 1988. - Sclerophyllous vegetation dynamics in the North of the Iberian peninsula during the last 16,000 years. Global Ecol. Biogeogr. Lett., 7, 335-351.

Ramil-Rego P., Sobrino C., Rodríguez M. \& Gómez-Orellana L. 1998. - Differences in the vegetation of the North Iberian peninsula during the last 16,000 years. Plant Ecol., 138, 41-62.

Rodríguez S.E., Fernández-Alaez C., Fernández -Alaez M. \& Bécares E. 1994. - Caracterización de las comunidades de macroinvertebrados de la cuenca alta des River Cares (NO España). Limnética, 10, 93-100.

Sánchez-Ortega A. \& Alba-Tercedor J. 1987. — Lista faunística y bibliográfica de los Plecópteros (Plecóptera) de la Península Ibérica. Listas de la flora y fauna de las aguas continentales de la Península Ibérica. Asoc. esp. Limnol., 4, 1-133.

Sánchez-Ortega A. \& Tierno J.M. 1996. - Current situation of stonefly fauna (Insecta: Plecoptera) in the Iberian Peninsula and the Balearic Islands. Mitt. Schweiz. ent. Ges., 69, 77-94.

Teer Braak C. J.F. 1988-1991. - Canoco - A Fortran program for canonical community ordination by (Partial) (detrended) (canonical) correspondence analysis, principal component analysis and redundancy analysis (version 2.1), Report LWA -88-02.- Agricult. Mathematics Group, Wageneingen, The Netherlands.

Tierno de Figueroa J. M., Luzón-Ortega J. M. \& Sánchez-Ortega A 1997. - Presencia de Capnioneura libera (Navás, 1909) (Insecta, Plecoptera) en el sur de la Península Ibérica. Bol. Asoc. Esp. Ent., 21, 277-278.

Vidal López M. \& Membiela Iglesia P. 1993. - Algunos factores abióticos de distribución de los Efemerópteros y Plecópteros (Insecta) en las sierras Segundera, Cabrera y Teleno (NW Península Ibérica). Limnética, 9, 99-106.

Vinçon G. \& Pardo I. 2003. - Two New Nemoura Species from the northwestern Iberian Peninsula and the Pyrenees (Plecoptera, Nemouridae). Nouv. Rev. Ent., 20, 29-38.

Vinçon G. \& Ravizza C. 1998. - Three New Protonemura Species from the Cordillera Cantabrica, Spain (Plecoptera, Nemouridae). Nouv. Rev. Ent., 15, 249-255.

Vinçon G. \& Ravizza C. 1999. — The genus Rhabdiopteryx in the Iberian Peninsula, with the description of $R$. antoninoi sp. n. (Plecoptera, Taeniopterygidae). Nouv. Rev. Ent., 16, 187-193.

Vinçon G. \& Ravizza C. 2001. — New micropterous micro-endemic Leuctra species and subspecies from the Spanish Cordillera Cantabrica (Plecoptera Leuctridae). Bol. Soc. entomol. Ital., 132 195-203.

Vinçon G. \& Sánchez-Ortega A. 2002. — The genus Capnioneura in the Iberian Peninsula and the Pyrenees, with the description of C. narcea sp. n. (Plecoptera, Capniidae). Nouv. Rev. Ent., 19 , $73-81$.

Whytton da Terra L. 1979. - Notes on the Portuguese Plecoptera. Gewässer und Abwässer, 64, 60-68.

Zwick P. 1967. - Revision der Gattung Chloroperla Newman (Plecoptera). Mitt. Schweiz. ent. Ges., 40, 1-26.

Zwick P. 1972. - Die Plecopteren Pictets und Burmeisters, mit Angaben ber weitere Arten (Insecta). Rev. Suisse Zool., 78, 1123-1194.
Zwick P. 1972. — Plecoptera (Ins.) aus dem Mittelmeergebiet, vor allem aus Portugal und Spanien. Ciencia Biologica (Portugal), 1, 7-17.

Zwick P. 1978. - Steinfliegen (Insecta, Plecoptera) aus Griechenland und benachbarten Ländern. 2 Teil. Mitt. Schweiz. ent. Ges., 51, 213-239.

\section{APPENDIX 1: List of stations}

1 Navarra, Sierra de Aralar, Alto de Lizzarusti, brook, tr. of River Araquil, 42 $58^{\prime} \mathrm{N}, 2^{\circ} 04^{\prime} \mathrm{W}$, alt. $600 \mathrm{~m}$

2 Guipúzcoa, Sierra de Aralar, Alto de Lizzarusti, brook, tr. of River Oria, $42^{\circ} 59^{\prime} \mathrm{N}, 2^{\circ} 04^{\prime} \mathrm{W}$, alt. $1000 \mathrm{~m}$

3 Guipúzcoa, Sierra de Aralar, above Zaldibia, brook, tr. of River Oria, $43^{\circ} 01^{\prime} \mathrm{N}, 2^{\circ} 04^{\prime} \mathrm{W}$

4 Guipúzcoa, Sierra de Aralar, Aritzalde de Otzaurte, brook, tr. of River Araquil, $42^{\circ} 55^{\prime} \mathrm{N}, 2^{\circ} 18^{\prime} \mathrm{W}$, alt. $700 \mathrm{~m}$

5 Guipúzcoa, Sierra de Urquilla, Arántzazu, torrent, tr. of River Ubao, 4258'N, 2²2’W, alt. $1000 \mathrm{~m}$

6 Alava, Peña Gorbea, near Gorbea reservoir, torrent, tr. of River Zadorra, $42^{\circ} 58^{\prime} \mathrm{N}, 2^{\circ} 43^{\prime} \mathrm{W}$, alt. $800 \mathrm{~m}$

7 Alava, Peña Gorbea, Mairuelegorreta caves, brook, tr. of River Zadorra, $42^{\circ} 59^{\prime} \mathrm{N}, 2^{\circ} 43^{\prime} \mathrm{W}$, alt. $1000 \mathrm{~m}$

8 Alava, Puerto de Orduña, northern slope, brook, tr. of River Nervion, $42^{\circ} 58^{\prime} \mathrm{N}, 3^{\circ} 01^{\prime} \mathrm{W}$, alt. $850 \mathrm{~m}$

9 Burgos, Portillo de la Sóa, brook, tr. of River Trueba, $43^{\circ} 08^{\prime} \mathrm{N}$, $3^{\circ} 25^{\prime} \mathrm{W}$, alt. $1000 \mathrm{~m}$

10 Burgos, Puerto de la Sia, brook, tr. of River Trueba, $43^{\circ} 08^{\prime} \mathrm{N}$, $3^{\circ} 34^{\prime} \mathrm{W}$, alt. $1150 \mathrm{~m}$

11 Burgos, Puerto de las Estacas de Trueba, torrent, River Trueba, $43^{\circ} 07^{\prime} \mathrm{N}, 3^{\circ} 40^{\prime} \mathrm{W}$, alt. $1150 \mathrm{~m}$

12 Burgos, Puerto de Escudo, spring, tr. of Ebre river, $43^{\circ} 03^{\prime} \mathrm{N}$, $3^{\circ} 53^{\prime} \mathrm{W}$, alt. $950 \mathrm{~m}$

13 Cantabria, Portillo de la Sóa, torrent, tr. of River Calera, $43^{\circ} 09^{\prime} \mathrm{N}, 3^{\circ} 26^{\prime} \mathrm{W}$, alt. $850 \mathrm{~m}$

14 Cantabria, Puerto de la Sia, brook, tr. of River Gandara, $43^{\circ} 10^{\prime} \mathrm{N}$, 33' W, alt. $1100 \mathrm{~m}$

15 Cantabria, Portillo de Luñada, above Mirones, River Miera, $43^{\circ} 12^{\prime} \mathrm{N}, 3^{\circ} 41^{\prime} \mathrm{W}$

16 Cantabria, Puerto de las Estacas de Trueba, spring, River Pas, $43^{\circ} 08^{\prime} \mathrm{N}, 3^{\circ} 42^{\prime} \mathrm{W}$, alt. $1150 \mathrm{~m}$

17 Cantabria, Puerto de las Estacas de Trueba, torrent, River Pas, $43^{\circ} 08^{\prime} \mathrm{N}, 3^{\circ} 43^{\prime} \mathrm{W}$, alt. $900 \mathrm{~m}$

18 Cantabria, Puerto de las Estacas de Trueba, above Yera, spring, tr. of River Pas, $43^{\circ} 08^{\prime} \mathrm{N}, 3^{\circ} 45^{\prime} \mathrm{W}$, alt. $800 \mathrm{~m}$

19 Cantabria, Puerto de la Magdalena, spring, tr. of River Pas, $43^{\circ} 03^{\prime} \mathrm{N}, 3^{\circ} 49^{\prime} \mathrm{W}$, alt. $850 \mathrm{~m}$

20 Cantabria, Puerto de Escudo, brook, tr. of River Pas, $43^{\circ} 05^{\prime} \mathrm{N}$, $3^{\circ} 53^{\prime} \mathrm{W}$, alt. $800 \mathrm{~m}$

21 Cantabria, Puerto de Palombera, brook, tr. of River Saja, $43^{\circ} 05^{\prime} \mathrm{N}, 4^{\circ} 13^{\prime} \mathrm{W}$, alt. $1200 \mathrm{~m}$

22 Cantabria, Reinosa, La Lomba, Puente de Riaño, torrent, Ebre river, $43^{\circ} 01^{\prime} \mathrm{N}, 4^{\circ} 16^{\prime} \mathrm{W}$, alt. $1000 \mathrm{~m}$

23 Cantabria, Puerto de Palombera, torrent, River Saja, $43^{\circ} 06^{\prime} \mathrm{N}$, $4^{\circ} 16^{\prime} \mathrm{W}$, alt. $900 \mathrm{~m}$ 
24 Cantabria, Reinosa, west Branavieja, torrent, tr. of Ebre river, $43^{\circ} 01^{\prime} \mathrm{N}, 4^{\circ} 21^{\prime} \mathrm{W}$, alt. $1500 \mathrm{~m}$

25 Cantabria, above Branavieja, spring, Fuente del Chivo, $43^{\circ} 04^{\prime} \mathrm{N}$, $4^{\circ} 22^{\prime} \mathrm{W}$, alt. $2000 \mathrm{~m}$

26 Cantabria, Puerto de Piedrasluengas, brook, tr. of River Nansa, $43^{\circ} 05^{\prime} \mathrm{N}, 4^{\circ} 28^{\prime} \mathrm{W}$, alt. $1250 \mathrm{~m}$

27 Cantabria, Above Potes, brook, tr. of River Deva, $43^{\circ} 09^{\prime} \mathrm{N}$ $4^{\circ} 43^{\prime} \mathrm{W}$, alt. $400 \mathrm{~m}$

28 Cantabria, Puerto de San Glorio, brook, River Quiviesa, $43^{\circ} 04^{\prime} \mathrm{N}, 4^{\circ} 46^{\prime} \mathrm{W}$, alt. $1600 \mathrm{~m}$

29 Cantabria, Picos Europa, Chalet Real, spring, River Duje, $43^{\circ} 10^{\prime} \mathrm{N}, 4^{\circ} 48^{\prime} \mathrm{W}$, alt. $1700 \mathrm{~m}$

30 Cantabria, Picos de Europa, Fuente De, spring, River Deva, $43^{\circ} 08^{\prime} \mathrm{N}, 4^{\circ} 51^{\prime} \mathrm{W}$, alt. $1070 \mathrm{~m}$

31 Asturias, Picos de Europa, near Sotres, brook, tr. of River Duje, $43^{\circ} 13^{\prime} \mathrm{N}, 4^{\circ} 45^{\prime} \mathrm{W}$, alt. $1000 \mathrm{~m}$

32 Asturias, Sierra Cuera, east Cangas de Onis, Escobal, torrent, tr. of River Sella, $43^{\circ} 21^{\prime} \mathrm{N}, 4^{\circ} 55^{\prime} \mathrm{W}$

33 Asturias, Picos de Europa, refugio de Vega Redonda, spring, River Junjumia, $43^{\circ} 12^{\prime} \mathrm{N}, 5^{\circ} 01^{\prime} \mathrm{W}$, alt. $1400 \mathrm{~m}$

34 Asturias, Picos de Europa, near Lago de Enol, brook, River Pomperi, $43^{\circ} 14^{\prime} \mathrm{N}, 5^{\circ} 01^{\prime} \mathrm{W}$, alt. $1200 \mathrm{~m}$

35 Asturias, above Viego, spring, River Santa Bustia, tr. of River Sella, $43^{\circ} 10^{\prime} \mathrm{N}, 5^{\circ} 07^{\prime} \mathrm{W}$, alt. $1000 \mathrm{~m}$

36 Asturias, above Beleño, spring, tr. of River Ponga, $43^{\circ} 10^{\prime} \mathrm{N}$, $5^{\circ} 08^{\prime} \mathrm{W}$, alt. $1000 \mathrm{~m}$

37 Asturias, above Sobrefoz, brook, Arroyo Ventaniella, tr. of River Ponga, $43^{\circ} 08^{\prime} \mathrm{N}, 5^{\circ} 10^{\prime} \mathrm{W}$

38 Asturias, above Sotos, torrent, tr. of River Ponga, $43^{\circ} 09^{\prime} \mathrm{N}$, $5^{\circ} 10^{\prime} \mathrm{W}$

39 Asturias, above Cazo, torrent, tr. of River Ponga, $43^{\circ} 17^{\prime} \mathrm{N}$, $5^{\circ} 11^{\prime} \mathrm{W}$, alt. $1000 \mathrm{~m}$

40 Asturias, Puerto de Tarna, brook, River Nalon, $43^{\circ} 07^{\prime} \mathrm{N}$, $5^{\circ} 13^{\prime} \mathrm{W}$, alt. $1450 \mathrm{~m}$

41 Asturias, Puerto de Tarna, below the pass, brook, River Nalon, $43^{\circ} 08^{\prime} \mathrm{N}, 5^{\circ} 14^{\prime} \mathrm{W}$, alt. $1200 \mathrm{~m}$

42 Asturias, above El Pico, torrent, River Tendi, tr. of River Pilona, $43^{\circ} 19^{\prime} \mathrm{N}, 5^{\circ} 14^{\prime} \mathrm{W}$, alt. $900 \mathrm{~m}$

43 Asturias, Below Puerto de Tarna, Pendones, torrent, River Nalon, $43^{\circ} 09^{\prime} \mathrm{N}, 5^{\circ} 16^{\prime} \mathrm{W}$, alt. $800 \mathrm{~m}$

44 Asturias, Puerto de San Isidro, brook, River san Isidro, $43^{\circ} 04^{\prime} \mathrm{N}$, $5^{\circ} 25^{\prime} \mathrm{W}$, alt. $1500 \mathrm{~m}$

45 Asturias, Puerto de Pajares, brook, tr. of River Pajares, $43^{\circ} 01^{\prime} \mathrm{N}$, $5^{\circ} 47^{\prime} \mathrm{W}$, alt. $1350 \mathrm{~m}$

46 León, Puerto de San Glorio, brook, tr. of River Yuso, $43^{\circ} 04^{\prime} N$, $4^{\circ} 47^{\prime} \mathrm{W}$, alt. $1550 \mathrm{~m}$

47 León, Picos de Europa, Puerto de Pandetrave, brook, tr. of River Cares, $43^{\circ} 07^{\prime} \mathrm{N}, 4^{\circ} 53^{\prime} \mathrm{W}$, alt. $1500 \mathrm{~m}$

48 León, Picos de Europa, Puerto de Pandetrave, brook, tr. of River Cares, $43^{\circ} 08^{\prime} \mathrm{N}, 4^{\circ} 54^{\prime} \mathrm{W}$, alt. $1400 \mathrm{~m}$

49 León, Picos de Europa, Puerto de Panderruedas, brook, tr. of River Sella, $43^{\circ} 08^{\prime} \mathrm{N}, 4^{\circ} 58^{\prime} \mathrm{W}$, alt. $1450 \mathrm{~m}$

50 León, Picos de Europa, Puerto de Panderruedas, brook, tr. of River Esla, $43^{\circ} 06^{\prime} \mathrm{N}, 5^{\circ} 00^{\prime} \mathrm{W}$, alt. $1300 \mathrm{~m}$

51 León, Picos de Europa, Puerto del Pontón, brook, tr. of River Sella, $43^{\circ} 07^{\prime} \mathrm{N}, 5^{\circ} 02^{\prime} \mathrm{W}$, alt. $1200 \mathrm{~m}$
52 León, Picos de Europa, Puerto del Pontón, brook, tr. of River Sella, $43^{\circ} 09^{\prime} \mathrm{N}, 5^{\circ} 03^{\prime} \mathrm{W}$, alt. $1000 \mathrm{~m}$

53 León, Puerto de los Señales, brook, tr. of River Porma, $43^{\circ} 04^{\prime} \mathrm{N}$, $5^{\circ} 14^{\prime} \mathrm{W}$, alt. $1600 \mathrm{~m}$

54 León, Puerto de los Señales, brook, tr. of River Esla, $43^{\circ} 03^{\prime} \mathrm{N}$, $5^{\circ} 15^{\prime} \mathrm{W}$, alt. $1500 \mathrm{~m}$

55 Asturias, highway Oviedo-León, after Negron tunnel, tr. of River Pajares, $43^{\circ} 01^{\prime} \mathrm{N}, 5^{\circ} 48^{\prime} \mathrm{W}$, alt. $900 \mathrm{~m}$

56 Asturias, highway Oviedo-León, before Negron tunnel, tr. of River Pajares, $43^{\circ} 02^{\prime} \mathrm{N}, 5^{\circ} 48^{\prime} \mathrm{W}$, alt. $800 \mathrm{~m}$

57 Asturias, Peña Ubiña, Puerto de la Cubilla, brook, River Huerna, $43^{\circ} 00^{\prime} \mathrm{N}, 5^{\circ} 55^{\prime} \mathrm{W}$, alt. $1500 \mathrm{~m}$

58 Asturias, Peña Ubiña, above Tuiza, spring, River Huerna, $43^{\circ} 01^{\prime} \mathrm{N}, 5^{\circ} 55^{\prime} \mathrm{W}$, alt. $1600 \mathrm{~m}$

59 Asturias, Puerto de Ventana, brook, tr. of River Tererga, $43^{\circ} 04^{\prime} \mathrm{N}, 6^{\circ} 01^{\prime} \mathrm{W}$, alt. $1450 \mathrm{~m}$

60 Asturias, Puerto de Ventana, torrent, River Ortigosa, tr. of River Tererga, $43^{\circ} 05^{\prime} \mathrm{N}, 6^{\circ} 02^{\prime} \mathrm{W}$, alt. $1200 \mathrm{~m}$

61 Asturias, Puerto de Somiedo, la Peral, brook, tr. of River Somiedo, $43^{\circ} 02^{\prime} \mathrm{N}, 6^{\circ} 15^{\prime} \mathrm{W}$, alt. $1300 \mathrm{~m}$

62 Asturias, Sierra de Begega, above Selviella, brook, tr. of River Somiedo, $43^{\circ} 19^{\prime} \mathrm{N}, 6^{\circ} 15^{\prime} \mathrm{W}$, alt. $850 \mathrm{~m}$

63 Asturias, Sierra de Begega, above Belmonte, brook, tr. of River Somiedo, $43^{\circ} 17^{\prime} \mathrm{N}, 6^{\circ} 16^{\prime} \mathrm{W}$, alt. $900 \mathrm{~m}$

64 Asturias, Sierra de Begega, above Selviella, brook, tr. of River Narcea, $43^{\circ} 19^{\prime} \mathrm{N}, 6^{\circ} 16^{\prime} \mathrm{W}$, alt. $1000 \mathrm{~m}$

65 Asturias, Puerto de Leitariegos, spring, tr. of River Naviego, $42^{\circ} 59^{\prime} \mathrm{N}, 6^{\circ} 25^{\prime} \mathrm{W}$, alt. $1500 \mathrm{~m}$

66 Asturias, Puerto de Leitariegos, Brañas de Arriba, torrent, River Naviego, $43^{\circ} 00^{\prime} \mathrm{N}, 6^{\circ} 27^{\prime} \mathrm{W}$, alt. $1200 \mathrm{~m}$

67 Asturias, Puerto de Leitariegos, under Vallado, brook, tr. of River Naviego, $43^{\circ} 03^{\prime} \mathrm{N}, 6^{\circ} 29^{\prime} \mathrm{W}$, alt. $1100 \mathrm{~m}$

68 Asturias, Santullano de Tineo, brook, tr. of River Narcea, $43^{\circ} 18^{\prime} \mathrm{N}, 6^{\circ} 30^{\prime} \mathrm{W}$, alt. $900 \mathrm{~m}$

69 Asturias, between Gera and Pola de Allande, brook, tr. of River Narcea, $43^{\circ} 17^{\prime} \mathrm{N}, 6^{\circ} 33^{\prime} \mathrm{W}$, alt. $850 \mathrm{~m}$

70 Asturias, Puerto de Palo, spring, Fuente de las Muyeres, $43^{\circ} 17^{\prime} \mathrm{N}, 6^{\circ} 40^{\prime} \mathrm{W}$, alt. $1100 \mathrm{~m}$

71 Asturias, Puerto de Palo, crossroad to Bendon, brook, tr. of River Arganza, $43^{\circ} 18^{\prime} \mathrm{N}, 6^{\circ} 40^{\prime} \mathrm{W}$, alt. $900 \mathrm{~m}$

72 León, Peña Ubiña, brook, tr. of River Luna, $42^{\circ} 59^{\prime} \mathrm{N}, 5^{\circ} 56^{\prime} \mathrm{W}$, alt. $1500 \mathrm{~m}$

73 León, Cuevas del Sil, south Villablino, spring, tr. of Sil, $42^{\circ} 54^{\prime} \mathrm{N}, 6^{\circ} 25^{\prime} \mathrm{W}$, alt. $950 \mathrm{~m}$

74 Lugo, Serra del Xistral, Santo Tomé, $43^{\circ} 32^{\prime}$ N, $7^{\circ} 29^{\prime} \mathrm{W}$, alt. $500 \mathrm{~m}$

75 Lugo, Serra del Xistral, Penido novo, $43^{\circ} 32^{\prime} \mathrm{N}, 7^{\circ} 31^{\prime} \mathrm{W}$, alt. $690 \mathrm{~m}$

76 Lugo, Serra del Xistral, brook, spring Chan do Eume, $43^{\circ} 27^{\prime} \mathrm{N}$, $7^{\circ} 34^{\prime} \mathrm{W}$, alt. $700 \mathrm{~m}$

77 Lugo, Miño catchment, River arnela, $43^{\circ} 22^{\prime} \mathrm{N}, 7^{\circ} 31^{\prime} \mathrm{W}$, alt. $640 \mathrm{~m}$

78 Lugo, Miño catchment, River castromaior, $43^{\circ} 20^{\prime} \mathrm{N}, 7^{\circ} 32^{\prime} \mathrm{W}$, alt. $440 \mathrm{~m}$

79 Lugo, Miño catchment, spring, Fonte toxoso, $43^{\circ} 24^{\prime} \mathrm{N}, 7^{\circ} 34^{\prime} \mathrm{W}$, alt. $820 \mathrm{~m}$ 
80 Lugo, Serra do Courel, Porto de Pedrafita, brook, tr. of River Navia, $42^{\circ} 43^{\prime} \mathrm{N}, 7^{\circ} 03^{\prime} \mathrm{W}$, alt. $1000 \mathrm{~m}$

81 Lugo, Serra do Courel, below Alto el Poyo, brook, tr. of River Lor, $42^{\circ} 42^{\prime} \mathrm{N}, 7^{\circ} 04^{\prime} \mathrm{W}$, alt. $1200 \mathrm{~m}$

82 Lugo, Serra do Courel, below Parada, brook, tr. of River Lor, $42^{\circ} 38^{\prime} \mathrm{N}, 7^{\circ} 05^{\prime} \mathrm{W}$, alt. $1000 \mathrm{~m}$

83 Lugo, Serra do Courel, below Santa Eufemia, torrent, tr. of River Lor, $42^{\circ} 36^{\prime} \mathrm{N}, 7^{\circ} 09^{\prime} \mathrm{W}$

84 Ourense, Cabeza de Manzaneda, brook, River San Lorenzo, $42^{\circ} 17^{\prime} \mathrm{N}, 7^{\circ} 12^{\prime} \mathrm{W}$, alt. $1600 \mathrm{~m}$

85 Ourense, Cabeza de Manzaneda, below Cova, torrent, tr. of River de Queixa, $42^{\circ} 18^{\prime} \mathrm{N}, 7^{\circ} 13^{\prime} \mathrm{W}$

86 Ourense, Manzaneda mountains, brook, Arroyo de los Campos, $42^{\circ} 14^{\prime} \mathrm{N}, 7^{\circ} 18^{\prime} \mathrm{W}$, alt. $1680 \mathrm{~m}$

87 Ourense, Manzaneda mountains, brook, Arroyo Seixo, $42^{\circ} 11^{\prime} \mathrm{N}$, $7^{\circ} 20^{\prime} \mathrm{W}$, alt. $1660 \mathrm{~m}$

88 Ourense, Manzaneda mountains, brook, $42^{\circ} 12^{\prime} \mathrm{N}, 7^{\circ} 21^{\prime} \mathrm{W}$, alt $1650 \mathrm{~m}$

89 Ourense, Manzaneda mountains, brook, $42^{\circ} 11^{\prime} \mathrm{N}, 7^{\circ} 22^{\prime} \mathrm{W}$, alt. $1420 \mathrm{~m}$

90 Ourense, Invernadeiro mountains, brook, $42^{\circ} 08^{\prime} \mathrm{N}, 7^{\circ} 16^{\prime} \mathrm{W}$, alt. $1340 \mathrm{~m}$

91 Ourense, Invernadeiro mountains, brook, $42^{\circ} 07^{\prime} \mathrm{N}, 7^{\circ} 17^{\prime} \mathrm{W}$, alt. $900 \mathrm{~m}$

92 Ourense, Invernadeiro mountains, torrent, $42^{\circ} 07^{\prime} \mathrm{N}, 7^{\circ} 17^{\prime} \mathrm{W}$, alt. $900 \mathrm{~m}$

93 Ourense, Invernadeiro mountains, torrent, $42^{\circ} 07^{\prime} \mathrm{N}, 7^{\circ} 17^{\prime} \mathrm{W}$, alt. $900 \mathrm{~m}$

94 Ourense, Invernadeiro mountains, brook, Arroyo das Coladas, $42^{\circ} 09^{\prime} \mathrm{N}, 7^{\circ} 17^{\prime} \mathrm{W}$, alt. $1420 \mathrm{~m}$

95 Ourense, Invernadeiro mountains, torrent, $42^{\circ} 07^{\prime} \mathrm{N}, 7^{\circ} 18^{\prime} \mathrm{W}$, alt. $860 \mathrm{~m}$

96 Ourense, Invernadeiro mountains, brook, Arroyo de Beigarro, $42^{\circ} 08^{\prime} \mathrm{N}, 7^{\circ} 18^{\prime} \mathrm{W}$, alt. $1000 \mathrm{~m}$

97 Ourense, Invernadeiro mountains, torrent, $42^{\circ} 08^{\prime} \mathrm{N}, 7^{\circ} 19^{\prime} \mathrm{W}$, alt. $920 \mathrm{~m}$

98 Ourense, Invernadeiro mountains, brook, Arroyo de Agralleira, $42^{\circ} 09^{\prime} \mathrm{N}, 7^{\circ} 19^{\prime} \mathrm{W}$, alt. $1000 \mathrm{~m}$

99 Ourense, Invernadeiro mountains, brook, Arroyo Puxo de Mogos, $42^{\circ} 10^{\prime} \mathrm{N}, 7^{\circ} 19^{\prime} \mathrm{W}$, alt. $1100 \mathrm{~m}$
100 Ourense, Invernadeiro mountains, brook, Arroyo Puxo de Mogos, $42^{\circ} 10^{\prime} \mathrm{N}, 7^{\circ} 19^{\prime} \mathrm{W}$, alt. $1160 \mathrm{~m}$

101 Ourense, Invernadeiro mountains, brook, $42^{\circ} 11^{\prime} \mathrm{N}, 7^{\circ} 19^{\prime} \mathrm{W}$, alt. $1420 \mathrm{~m}$

102 Ourense, Invernadeiro mountains, small river, $42^{\circ} 07^{\prime} \mathrm{N}$, $7^{\circ} 20^{\prime} \mathrm{W}$, alt. $1000 \mathrm{~m}$

103 Ourense, Invernadeiro mountains, brook, $42^{\circ} 07^{\prime} \mathrm{N}, 7^{\circ} 20^{\prime} \mathrm{W}$, alt. $920 \mathrm{~m}$

104 Ourense, Invernadeiro mountains, big river, $42^{\circ} 09^{\prime} \mathrm{N}, 7^{\circ} 20^{\prime} \mathrm{W}$, alt. $1000 \mathrm{~m}$

105 Ourense, Invernadeiro mountains, torrent, $42^{\circ} 09^{\prime} \mathrm{N}, 7^{\circ} 20^{\prime} \mathrm{W}$, alt. $920 \mathrm{~m}$

106 Ourense, Invernadeiro mountains, torrent, $42^{\circ} 09^{\prime} \mathrm{N}, 7^{\circ} 20^{\prime} \mathrm{W}$, alt. $1000 \mathrm{~m}$

107 Ourense, Invernadeiro mountains, River Casarello, $42^{\circ} 11^{\prime} \mathrm{N}$, $7^{\circ} 22^{\prime} \mathrm{W}$, alt. $1500 \mathrm{~m}$

108 Ourense, near Bouza, north A Gudiña, brook, tr. of River Camba, $42^{\circ} 05^{\prime} \mathrm{N}, 7^{\circ} 05^{\prime} \mathrm{W}$

109 Ourense, Viana del Bollo, torrent, tr. of River Bibei, $42^{\circ} 12^{\prime} \mathrm{N}$, $7^{\circ} 06^{\prime} \mathrm{W}$

110 Zamora, Sanabria, above El Puente, torrent, River Tera, $42^{\circ} 07^{\prime} \mathrm{N}, 6^{\circ} 38^{\prime} \mathrm{W}$, alt. $850 \mathrm{~m}$

111 Zamora, Sanabria, above San Ciprián, brook, tr. of River Tera, $42^{\circ} 11^{\prime} \mathrm{N}, 6^{\circ} 43^{\prime} \mathrm{W}$

112 Burgos, Sierra de la Demanda, Pradilla de Belorado, tr. River Tiron, $42^{\circ} 18^{\prime} \mathrm{N}, 3^{\circ} 07^{\prime} \mathrm{W}$

113 Rioja, Sierra de la Demanda, above Valganón, tr. River Oja , $42^{\circ} 18^{\prime} \mathrm{N}, 3^{\circ} 05^{\prime} \mathrm{W}$

114 Rioja, Sierra de la Demanda, Ojacastro, River Oja , $42^{\circ} 19^{\prime} \mathrm{N}, 3^{\circ} 00^{\prime} \mathrm{W}$

115 Rioja, Sierra de la Demanda, before Valdezcaray ski station, tr. River Oja , $42^{\circ} 17^{\prime} \mathrm{N}, 3^{\circ} 03^{\prime} \mathrm{W}$

116 Rioja, Sierra de la Demanda, above Valdezcaray ski station, tr. River Oja , $42^{\circ} 16^{\prime} \mathrm{N}, 3^{\circ} 03^{\prime} \mathrm{W}$

117 Zaragoza, Sierra del Moncayo, road to San Martin de la Virgen de Moncayo, $1700 \mathrm{~m}, 41^{\circ} 47^{\prime} \mathrm{N}, 1^{\circ} 51^{\prime} \mathrm{W}$

118 Zaragoza, Sierra del Moncayo, Fuente del Sacristan and Fuente de los tres Canos, $41^{\circ} 48^{\prime} \mathrm{N}, 1^{\circ} 51^{\prime} \mathrm{W}$ 